\title{
Fate of the nitrate radical at the summit of a semi-rural mountain site in Germany assessed with direct reactivity measurements
}

Patrick Dewald, Clara M. Nussbaumer, Jan Schuladen, Akima Ringsdorf, Achim Edtbauer, Horst Fischer, Jonathan Williams, Jos Lelieveld and John N. Crowley

5 Atmospheric Chemistry Department, Max Planck Institut für Chemie, 55128 Mainz, Germany

Correspondence to: John N. Crowley (john.crowley@ mpic.de)

Abstract. The reactivity of $\mathrm{NO}_{3}$ plays an important role in modifying the fate of reactive nitrogen species at nighttime. High reactivity (e.g. towards unsaturated VOCs) can lead to formation of organic nitrates and secondary organic aerosol, whereas low reactivity opens the possibility of heterogeneous $\mathrm{NO}_{\mathrm{X}}$ losses via formation and uptake of $\mathrm{N}_{2} \mathrm{O}_{5}$ to particles.

We present direct $\mathrm{NO}_{3}$ reactivity measurements $\left(k^{\mathrm{NO}_{3}}\right)$ that quantify the VOC-induced losses of $\mathrm{NO}_{3}$ during the TO2021 campaign at the summit of the Kleiner Feldberg mountain ( $825 \mathrm{~m}$, Germany) in July 2021. $k^{\mathrm{NO}_{3}}$ was on average $\sim 0.035 \mathrm{~s}^{-1}$ during the daytime, $\sim 0.015 \mathrm{~s}^{-1}$ for almost half of the nights and below the detection limit of $0.006 \mathrm{~s}^{-1}$ for the other half, which may be linked to sampling from above the nocturnal surface layer. $\mathrm{NO}_{3}$ reactivities derived from $\mathrm{VOC}$ measurements and the corresponding rate coefficient were in good agreement with $k^{\mathrm{NO}_{3}}$, with monoterpenes representing $84 \%$ of the total reactivity. The fractional contribution $F$ of $k^{\mathrm{NO}_{3}}$ to the overall $\mathrm{NO}_{3}$ loss rate (which includes additional reaction of $\mathrm{NO}_{3}$ with $\mathrm{NO}$ and photolysis) were on average $\sim 16 \%$ during the daytime and $\sim 50-60 \%$ during the nighttime. The relatively low nighttime value of $F$ is related to the presence of several tens of pptv of $\mathrm{NO}$ on several nights. $\mathrm{NO}_{3}$ mixing ratios were not measured but steadystate calculations resulted in nighttime values between $<1 \mathrm{pptv}$ and $12 \mathrm{pptv}$. A comparison of results from TO2021 with direct measurements of $\mathrm{NO}_{3}$ during previous campaigns between 2008 and 2015 at this site revealed that $\mathrm{NO}_{3}$ loss rates were remarkably high during $\mathrm{TO} 2021$, while $\mathrm{NO}_{3}$ production rates were low.

We observed NO mixing ratios of up to $80 \mathrm{pptv}$ at night which has implications for the cycling of reactive nitrogen at this site. With $\mathrm{O}_{3}$ present at levels of mostly 25 to $60 \mathrm{ppbv}$, $\mathrm{NO}$ is oxidised to $\mathrm{NO}_{2}$ on a time-scale of a few minutes. We find that to maintain NO mixing ratios of e.g. 40 pptv requires a ground-level $\mathrm{NO}$ emission rate of $0.33 \mathrm{pptv} \mathrm{s}^{-1}$ (into a shallow surface

25 layer of $10 \mathrm{~m}$ depth). This in turn requires rapid deposition of $\mathrm{NO}_{2}$ to the surface $\left(v d_{\mathrm{NO} 2} \sim 0.15 \mathrm{~cm} \mathrm{~s}^{-1}\right)$ to reduce nocturnal $\mathrm{NO}_{2}$ levels to match the observations.

\section{Introduction}

Nitric oxide (NO) and nitrogen dioxide $\left(\mathrm{NO}_{2}\right)$ are atmospheric pollutants, which exert a great impact on climate and air quality (Pozzer et al., 2012; Lelieveld et al., 2020). $\mathrm{As}^{\mathrm{NO}_{2}}$ is the source of boundary layer ozone $\left(\mathrm{O}_{3}\right.$, which is phytotoxic and a cause 
30 of respiratory illness), understanding the processes that remove $\mathrm{NO}_{\mathrm{x}}\left(=\mathrm{NO}+\mathrm{NO}_{2}\right)$ are of great importance (Crutzen and Lelieveld, 2001; Lelieveld et al., 2016; Edwards et al., 2017). The formation of long-lived or soluble organic nitrates during the oxidation of volatile organic compounds (VOCs) provides a mechanism to convert $\mathrm{NO}_{\mathrm{X}}$ to $\mathrm{NO}_{Z}$ (where $\mathrm{NO}_{z}$ includes both organic and inorganic nitrates in the gas- and particle-phase), which may be transported away from the source region or removed via dry- or wet-deposition, respectively (Rollins et al., 2012; Present et al., 2020).

35 The major initiators of VOC oxidation are hydroxyl radicals $(\mathrm{OH})$, ozone $\left(\mathrm{O}_{3}\right)$ and the nitrate radical $\left(\mathrm{NO}_{3}\right)(\mathrm{Ng}$ et al., 2017 ;

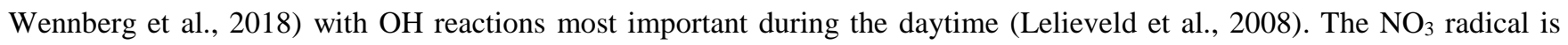
generally considered to be important only at nighttime (Brown and Stutz, 2012) although in some environments, it can also contribute substantially to the oxidation of unsaturated VOC during the day (Liebmann et al., 2018a; Liebmann et al., 2018b). $\mathrm{NO}_{3}$ is formed almost exclusively in the sequential oxidation of $\mathrm{NO}$ by $\mathrm{O}_{3}\left(\mathrm{R} 1\right.$ and $\mathrm{R} 2$ ). During daytime, $\mathrm{NO}_{3}$ is lost via rapid

40 photolysis (R5 and R6, with a lifetime of seconds) and an efficient reaction with $\mathrm{NO}\left(k_{7}=2.6 \times 10^{-11} \mathrm{~cm}^{3} \mathrm{molecule}^{-1} \mathrm{~s}^{-1}\right.$ at 298 K) (IUPAC, 2022), which result in low mixing ratios (Wayne et al., 1991). $\mathrm{NO}_{3}$ also reacts with $\mathrm{NO}_{2}$ to form dinitrogen pentoxide $\left(\mathrm{N}_{2} \mathrm{O}_{5}\right)$, which is in thermal equilibrium with $\mathrm{NO}_{3}$ and $\mathrm{NO}_{2}(\mathrm{R} 3, \mathrm{R} 4)$.

$\mathrm{NO}+\mathrm{O}_{3} \rightarrow \mathrm{NO}_{2}+\mathrm{O}_{2}$

$\mathrm{NO}_{2}+\mathrm{O}_{3} \rightarrow \mathrm{NO}_{3}+\mathrm{O}_{2}$

$45 \mathrm{NO}_{3}+\mathrm{NO}_{2}+\mathrm{M} \rightarrow \mathrm{N}_{2} \mathrm{O}_{5}+\mathrm{M}$

$\mathrm{N}_{2} \mathrm{O}_{5}+\mathrm{M} \rightarrow \mathrm{NO}_{3}+\mathrm{NO}_{2}+\mathrm{M}$

$\mathrm{NO}_{3}+\mathrm{hv} \rightarrow \mathrm{NO}+\mathrm{O}_{2}$

$\mathrm{NO}_{3}+\mathrm{hv} \rightarrow \mathrm{NO}_{2}+\mathrm{O}$

$\mathrm{NO}_{3}+\mathrm{NO} \rightarrow 2 \mathrm{NO}_{2}$

50 Reactions R1 - R4 can result in permanent loss of $\mathrm{NO}_{\mathrm{x}}$ from the gas phase through deposition or uptake to particles of e.g. $\mathrm{NO}_{3}$ or $\mathrm{N}_{2} \mathrm{O}_{5}$ (R8, R9) (Crowley et al., 2011; Phillips et al., 2016).

$\mathrm{N}_{2} \mathrm{O}_{5} \rightarrow$ particle (or deposition)

$\mathrm{NO}_{3} \rightarrow$ particle (or deposition)

In forested regions during the night, $\mathrm{NO}_{3}$ reacts predominantly with unsaturated volatile organic compounds (VOC) often of

55 biogenic origin such as isoprene or monoterpenes, which results in the formation of alkyl nitrates $\left(\mathrm{RONO}_{2}\right)(\mathrm{R} 10)($ Hallquist et al., 1999; Fry et al., 2014; Wu et al., 2021). Depending on the biogenic VOC involved, the $\mathrm{RONO}_{2}$ formed may have low volatility and may deposit to surfaces or transfer to the particle phase to form secondary organic aerosols (SOA) (R11) (Place et al., 2022). The reaction between $\mathrm{NO}_{3}$ and BVOC consequently represents a loss of $\mathrm{NO}_{\mathrm{X}}$ from the gas-phase and thus has an impact on air quality via suppression of ozone formation and increases in SOA levels (Fry et al., 2011; Romer Present et

60 al., 2020).

$\mathrm{NO}_{3}+\mathrm{VOC}\left(+\mathrm{O}_{2}\right) \rightarrow \rightarrow \mathrm{RONO} 2$

$\mathrm{RONO}_{2} \rightarrow$ deposition/SOA 
The nocturnal $\mathrm{NO}_{3}$ lifetime close to the surface is generally short (typically in the range of minutes) owing to the build-up in concentration of reactive gases emitted from the biosphere into a shallow nocturnal boundary layer (Liebmann et al., 2018a;

65 Liebmann et al., 2018b). Longer $\mathrm{NO}_{3}$ lifetimes (sometimes exceeding 1 hour) have been derived from $\mathrm{NO}_{3}$ measurements in very clean regions (Allan et al., 2000; Martinez et al., 2000), from measurements in the overlying residual layer using towers and aircraft platforms (Stutz et al, 2004; Brown et al., 2007a; Brown 2007b) and at mountain sites where the meteorological situation results in the measurement location being above the nocturnal surface layer (Carslaw et al., 1997; Brown et al., 2016; Sobanski et al., 2016).

70 The lifetime of $\mathrm{NO}_{3}$ has often been derived using a stationary-state approximation, which relies on direct measurements of $\mathrm{NO}_{3}, \mathrm{NO}_{2}$ and $\mathrm{O}_{3}$ (Heintz et al., 1996; Allan et al., 1999; Geyer et al., 2001; Brown et al., 2004; Brown et al., 2009; Stutz et al., 2010; Sobanski et al., 2016). This method is limited to periods when $\mathrm{NO}_{3}$ mixing ratios are above the instrumental detection limit, which (depending on instrument performance) may restrict the method to periods when $\mathrm{NO}_{3}$ production rates are high and $\mathrm{NO}_{3}$ reactivities (i.e. the inverse of $\mathrm{NO}_{3}$ lifetimes) are low. This is usually not the case during the daytime or even during

75 the nighttime in areas with high BVOC emissions (Liebmann et al., 2018a). Direct $\mathrm{NO}_{3}$ reactivity measurements not only extend the accessibility to daytime reactivities but also, together with measurements of $\mathrm{NO}, \mathrm{NO}_{3}$, photolysis rates $\left(\mathrm{NO}_{3}\right)$ and VOCs, enables the determination of the fate of the $\mathrm{NO}_{3}$ radical throughout the diel cycle. Recent direct $\mathrm{NO}_{3}$ reactivity measurements and model calculations (Liebmann et al., 2019; Foulds et al., 2021) suggest that $\mathrm{NO}_{3}$ also contributes to daytime alkyl nitrate formation, which typically occurs through the OH-initiated oxidation of BVOC in the presence of NO (Wennberg et al., 2018). Quantifying the contribution of $\mathrm{NO}_{3}+\mathrm{VOC}$ reactions to the $\mathrm{NO}_{3}$ reactivity is thus central in understanding the role of $\mathrm{NO}_{3}$, in e.g. $\mathrm{SOA}$ formation and $\mathrm{NO}_{\mathrm{X}}$ lifetimes.

In this study, the fate of the $\mathrm{NO}_{3}$ radical on the semi-rural Kleiner Feldberg mountain (in the south-west of Germany) in July and August 2021 (TO2021 campaign) during both day- and nighttime is analysed by direct measurements of NO, photolysis rates $\left(\mathrm{NO}_{3}\right)$ and the first-order $\mathrm{NO}_{3}$ loss-constant resulting from reaction with VOCs $\left(k^{\mathrm{NO}_{3}}\right)$. Measurements of VOCs that are 85 reactive towards $\mathrm{NO}_{3}$ enable us to calculate their fractional contribution to $k^{N O_{3}}$. With the help of $\mathrm{NO}_{3}, \mathrm{NO}_{2}, \mathrm{NO}$ and $\mathrm{O}_{3}$ measurements we derive $\mathrm{NO}_{3}$ loss-terms via the steady-state assumption $\left(\mathrm{L}_{\mathrm{NO}_{3}}\right)$ for previous campaigns at this site to assess the impact of differing meteorological and chemical conditions.

\section{The TO2021 campaign}

The TO2021 campaign took place in July and August 2021 at the Taunus Observatory (TO) at the summit of the Kleiner

90 Feldberg mountain ( $825 \mathrm{~m}$ above sea level). A detailed description of the location has been given elsewhere (Crowley et al., 2010) and only a brief summary is given here. The Kleiner Feldberg is mostly surrounded by coniferous forest, but an area at the summit $\left(\sim 100 \mathrm{~m}^{2}\right)$ is cleared of trees and hosts the meteorological measurements of the German Meteorological Service (Deutscher Wetterdienst, DWD) and permanent measurement containers of the University of Frankfurt and the Hessian Agency for Nature Conservation, Environment and Geology (Hessisches Landesamt für Naturschutz, Umwelt und Geologie, 
95 HLNUG). The summit itself is covered with bushes and, especially to the north, with blueberry shrubs. The mountain tops of Altkönig (798 $\mathrm{m}$ a.s.1.) and Großer Feldberg (878 $\mathrm{m}$ a.s.1.) are in the direct vicinity $(<3 \mathrm{~km})$. Air arriving from the south-west and south-east is impacted by anthropogenic emissions from the densely populated cities of Frankfurt, Wiesbaden and Mainz (20-30 km), whereas air from the north-west, north and north-east is cleaner, with no major cities for 50-70 km.

\subsection{Instrumentation}

100 For the duration of the TO2021 campaign, two (stacked) containers including the instruments operated by the Max-PlanckInstitute for Chemistry (MPIC) were set up on the site. If not stated otherwise, the instruments sampled from a high-volumeflow stainless-steel tube $\left(10 \mathrm{~m}^{3} \mathrm{~min}^{-1}, 0.2 \mathrm{~s}\right.$ residence time) sucking air from ca. $10 \mathrm{~m}$ above the ground. Each instrument with measurements used in the analysis is described below.

\subsection{1 $\mathrm{NO}_{3}$ reactivity}

105 The Flow-Tube Cavity Ring Down Spectrometer (FT-CRDS) setup used to quantify VOC-induced $\mathrm{NO}_{3}$ reactivity (Liebmann et al., 2017) consists of a Teflon coated (FEPD 121, Chemours) glass flow-tube reactor, in which a flow of ambient air is mixed with 30-60 parts per trillion per volume (pptv) of synthetically generated $\mathrm{NO}_{3}$.

$\mathrm{NO}_{3}$ is generated by the sequential oxidation of $\mathrm{NO}$ and $\mathrm{NO}_{2}\left(3.5 \mathrm{sccm}\right.$ of 1 parts per million per volume (ppmv) in $\mathrm{N}_{2}$, Air Liquide) by $\mathrm{O}_{3}$ (generated by passing synthetic air over a $\mathrm{Hg}$ lamp) in an upstream Teflon-coated glass reactor (thermostated

110 to $30^{\circ} \mathrm{C}$ at a pressure of $1.3 \mathrm{bar}$ ) in 400 standard (STP) cubic centimetre per minute ( $\mathrm{sccm}$ ) synthetic air. The flow exiting the $\mathrm{NO}_{3}$ source is passed through ca. $15 \mathrm{~cm} 1 / 4$ inch (in.) outer diameter (OD) PFA tubing that is heated to $140^{\circ} \mathrm{C}$ so that $\mathrm{N}_{2} \mathrm{O}_{5}$ is quantitatively decomposed to $\mathrm{NO}_{3}$ and $\mathrm{NO}_{2}(\mathrm{R} 4)$. The flow from the $\mathrm{NO}_{3}$ source is then mixed with either 2800 sccm synthetic or ambient air and passed through the flow-tube reactor where it resides for time $t$. The synthetic air used to measure zero reactivities was provided by a commercial zero-air generator (CAP 120, Fuhr GmbH) and humidified to ambient level with a

115 permeation tube (PermaPure, MH-070-24F-4) immersed in deionized water. The ambient air was sampled from the high-flow inlet through $1 / 4$ in. (OD) PFA tubing equipped with a Teflon membrane filter ( $2 \mu \mathrm{m}$ pore, $47 \mathrm{~mm}$ diameter, Pall Corp.).

$\mathrm{NO}_{3}$ surviving the flow-tube was detected by CRDS at $662 \mathrm{~nm}$. The ring-down time in the absence of $\mathrm{NO}_{3}$ was determined every ca. $5 \mathrm{~min}$ by adding an excess of $\mathrm{NO}\left(3 \mathrm{sccm}\right.$ of $100 \mathrm{ppmv}$ in $\mathrm{N}_{2}$ ). $\mathrm{NO}_{3}$ reactivities are deduced from the relative change in $\mathrm{NO}_{3}$ mixing ratio in ambient air compared to synthetic air. Dynamic dilution of the ambient air with synthetic air was used

120 to keep the $\mathrm{NO}_{3}$ reactivity in a measureable range when sampling highly reactive air masses.

Since the $\mathrm{NO}_{3}$ mixing ratio is affected by reactions $\mathrm{R} 1-\mathrm{R} 4, \mathrm{R} 7$ and $\mathrm{R} 9$ in addition to the reaction of interest (R10), a numerical simulation procedure that corrects for the impact of $\mathrm{NO}$ and $\mathrm{NO}_{2}$ is necessary to extract the $\mathrm{NO}_{3}$ reactivity towards VOCs $\left(k^{\mathrm{NO}_{3}}\right)$. The validity of this correction procedure was checked by adding a known amount of NO (1-6 sccm of 245 parts per billion per volume (ppbv) $\mathrm{NO}$ in $\mathrm{N}_{2}$, Air Liquide) every two hours during the zeroing periods throughout the campaign. As 125 shown in Fig. S1a of the Supplement, the model was able to reproduce the observed $\mathrm{NO}_{3}$ mixing ratios reliably. A further calibration sequence during the campaign, in which five different amounts of NO were added, is displayed in Fig. S1b. The 
flow-tube predominantly used during TO2021 features a residence time of $t=9.5 \mathrm{~s}$ and an $\mathrm{NO}_{3}$ wall loss rate of $0.001 \mathrm{~s}^{-1}$. The limit of detection (LOD) is mainly defined by the stability of the $\mathrm{NO}_{3}$ source and baseline, which were improved by thermostating both the $\mathrm{NO}_{3}$ source and the flowtube and insulating the cavity from thermal gradients in the container so that a signal-stabilty related uncertainty of $16 \%$ was achieved. For the numerical simulation procedure, ambient $\mathrm{O}_{3}, \mathrm{NO}_{\text {and }} \mathrm{NO}_{2}$ mixing ratios and rate coefficients for (R1-R4, R7) were deployed. Liebmann et al. (2017) showed with the help of Monte Carlo simulations that the uncertainty associated with this simulation is dependent on the ratio between ambient $\mathrm{NO}_{2}$ and $k^{\mathrm{NO}_{3}}$. Assuming a typical daytime situation for TO2021 $\left(k^{\mathrm{NO}_{3}} \sim 0.04 \mathrm{~s}^{-1},\left[\mathrm{NO}_{2}\right]=2 \mathrm{ppbv} \mathrm{\textrm {NO } _ { 2 }}\right)$ the numerical simulation introduces an uncertainty of $15 \%$, resulting in an overall uncertainty of $22 \%$. However, if for example $k^{\mathrm{NO}_{3}}$ is $0.006 \mathrm{~s}^{-1}$ in the presence of 1 ppbv $\mathrm{NO}_{2}$ (as occasionally detected during the nighttime), the uncertainty caused by the simulation increases to ca. $50 \%$. During TO2021, the instrument's LOD was $0.006 \mathrm{~s}^{-1}$ for this flowtube.

Between the $23^{\text {rd }}$ and $25^{\text {th }}$ July, a larger flow-tube was tested with the intention of extending the LOD to lower reactivities. The residence time (20 s during the day or $32 \mathrm{~s}$ during the night according to position of a moveable injector) and wall loss rates were characterised during the campaign as detailed by Liebmann et al. (2017). The factor $\sim 3$ longer residence time at night compared to the smaller flow-tube should have extended the LOD to $0.003 \mathrm{~s}^{-1}$. However, the larger flow-tube suffered from a larger $\mathrm{NO}_{3}$ wall loss rate $\left(>0.04 \mathrm{~s}^{-1}\right)$, which effectively worsened the LOD. For this reason, the deployment of this flowtube was stopped after two days.

During the nighttime, before being mixed with synthetic $\mathrm{NO}_{3}$, the air was sampled through a $2 \mathrm{~L}$ uncoated glass flask $(40 \mathrm{~s}$ residence time) that was heated to $35^{\circ} \mathrm{C}$. This ensures that ambient $\mathrm{NO}_{3}$ and $\mathrm{N}_{2} \mathrm{O}_{5}$ does not reach the flow tube to bias the measurement. The NO mixing ratios that were used in the numerical simulations were corrected (typically by a factor of 0.6) for the reaction with ambient $\mathrm{O}_{3}$ during residence in the flask.

\subsection{2 $\mathrm{NO}_{2}, \mathrm{NO}, \mathrm{O}_{3}$ and actinic flux}

Owing to the importance of co-located $\mathrm{NO}_{2}$ measurements for interpretation of the $k^{\mathrm{NO}_{3}}$ data, the FT-CRDS set up has a second inlet and cavity to measure $\mathrm{NO}_{2}$ (Liebmann et al., 2018b) with a total measurement uncertainty (defined by noise and baseline stability) of $8 \%$ and a LOD of $168 \mathrm{pptv}(4 \mathrm{~s})$. A further CRDS-based measurement of $\mathrm{NO}_{2}$ was made using a thermaldissociation cavity ring-down spectrometer (TD-CRDS) (Friedrich et al., 2020) for measurement of $\mathrm{NO}_{\mathrm{X}}$ and $\mathrm{NO}_{\mathrm{Y}}$. At nighttime, when $\mathrm{NO}$ was generally $<80$ pptv, the $\mathrm{NO}_{\mathrm{X}}$ channel of this instrument essentially measures $\mathrm{NO}_{2}$. The inlet of the $\mathrm{NO}_{\mathrm{X}} / \mathrm{NO}_{\mathrm{Y}}$ instrument was located on the container roof, $\sim 2 \mathrm{~m}$ to the north and $2 \mathrm{~m}$ lower than the top of the high-flow inlet. In addition, $\mathrm{NO}_{2}$ was measured with a chemiluminescence (CLD) setup (ECO Physics, CLD 790 SR) equipped with a photolytic converter to convert $\mathrm{NO}_{2}$ to $\mathrm{NO}$ (Tadic et al., 2020; Nussbaumer et al., 2021). This instrument also provided the campaign NO data-set. Calibration (using a dynamically diluted, secondary 5 ppm NO standard) was carried out every 2 hours. The LODs for $\mathrm{NO}$ and $\mathrm{NO}_{2}$ were 7 and 10 pptv, respectively, the total measurement uncertainties were 9 and $19 \%$ for NO and $\mathrm{NO}_{2}$. 
The three sets of $\mathrm{NO}_{2}$ measurements are compared in the Supplement (Fig. S2). A bivariate linear regression (York, 1966) of CRDS measurement is observed (slope of 0.99), while a fair agreement (slope of 1.09) within associated uncertainties is achieved for the intercomparison with the CLD measurement. $\mathrm{O}_{3}$ was measured via UV absorption with two identical, commercial ozone monitors (2B technologies, model 205) that were cross-calibrated after the campaign. The instrument background was estimated ca. every two days with synthetic air from the zero-air generator. The uncertainty associated with this measurement is $5 \%$ and the LOD is 2 ppbv.

Actinic flux measurements were made by a spectral radiometer (Metcon $\mathrm{GmbH}$ ) installed on top of the upper container and converted to photolysis frequencies for $\mathrm{NO}_{3}\left(\mathrm{~J}^{\mathrm{NO}}\right.$ ) using evaluated absorption cross sections and quantum yields (Burkholder et al., 2016) with an overall uncertainty of ca. $15 \%$ (Friedrich et al., 2021).

\subsubsection{VOC measurements}

170 VOCs were measured from the $15^{\text {th }}$ to $31^{\text {st }}$ July with a proton-transfer-reaction time-of-flight mass-spectrometer (PTR8000, IONICON Analytik GmbH) (Jordan et al., 2009; Bekö et al., 2020) with a time resolution of 20 s, operated with hydronium ions $\left(\mathrm{H}_{3} \mathrm{O}^{+}\right)$at a pressure of $2.2 \mathrm{mbar}$ and an $\mathrm{E} / \mathrm{N}$ of $137 \mathrm{Td}$. Mixing ratios of isoprene, monoterpenes and sesquiterpenes are derived from calibrating to a gas standard containing isoprene, $\alpha$-pinene and $\beta$-caryophyllene (Apel-Riemer Environmental Inc., Colorado, USA). The limit of detection lies in the range of tens of ppt and the uncertainty is defined to be below $20 \%$.

175 A second PTR-ToF-MS (VOCUS, Tofwerk AG) provided uncalibrated VOC data for the period between $20^{\text {th }}$ July and $6^{\text {th }}$ August (Krechmer et al., 2018). In order to extend data availability, the VOCUS data for isoprene, monoterpenes and sesquiterpenes were scaled to that of the PTR8000 data set during the common time period.

Both PTR-ToF-MS were located in a permanent container of the TO, ca. $8 \mathrm{~m}$ distant from the MPIC container. Air was sampled from the roof of the container (ca. $8 \mathrm{~m}$ ) through a heated inlet line equipped with a polytetrafluoroethylene (PTFE) filter.

\subsubsection{Temperature and relative humidity profiles}

Deployment of a drone (EVO-X12, multikopter.de) equipped with a commercial gas sensor (BME680, Bosch Sensortech $\mathrm{GmbH}$ ) enabled the measurement of vertical profiles of pressure, temperature and relative humidity (time resolution of $1 \mathrm{~s}$ ) to a height of $100 \mathrm{~m}$ AGL.

\section{Results and Discussion}

185 An overview of the key meteorological and trace-gas measurements used in the analysis for the TO2021 campaign period from July to August 2021 is given in Fig. 1. Grey shaded areas mark the nighttime periods; sunrise during the measurement period was at $\sim$ 03:30 and sunset at $\sim$ 19:30 UTC. $k^{\mathrm{NO}_{3}}$ shows a distinct daytime to nighttime variability and generally follows the 
summed mixing ratio of monoterpenes ( $\mathrm{MTS}$ ) which were present at maximum mixing ratios (during the day) of typically between 150 and 400 pptv.

Wind speeds were predominantly between 2 and $4 \mathrm{~m} \mathrm{~s}^{-1}$ with most wind-sectors represented, although wind from the east and south-east originating from the Frankfurt area (SE) were rarely encountered. The local wind-directions and speeds during TO2021 are displayed as a wind rose in Fig. S3a in the Supplement.

There were several periods of rain and fog during TO2021, which is reflected by high relative humidities (RH) mostly between 75 and $100 \%$ at moderate temperatures between 12 and $20^{\circ} \mathrm{C}$. Ozone mixing ratios varied between 20 and $60 \mathrm{ppbv}$. The CLD setup observed NO mixing ratios close to (10 to 20 pptv) or below the LOD of 7 pptv on ca. half of the nights, but also returned values of between 20 to 80 pptv for prolonged periods on some nights. Daytime NO mixing ratios were between 0.5 ppbv and 2 ppbv, with maximum values around midday. Spikes in NO mixing ratios caused by vehicles at the site were removed from the dataset. $\mathrm{NO}_{2}$ mixing ratios (as measured with the FT-CRDS setup) were generally between 1 and 2 ppbv, with occasional values of up to 6 ppbv. Photolysis rates of $\mathrm{NO}_{3}\left(\mathrm{NO}_{3}\right)$ of ca. $0.15 \mathrm{~s}^{-1}$ were detected at noon. The data-gap between the $3^{\text {rd }}$ and $2005^{\text {th }}$ July was caused by a power-failure.

\section{$3.1 \mathrm{NO}_{3}$ reactivity}

As is evident from Fig. $1, \mathrm{KO}^{\mathrm{NO}_{3}}$ followed the trend in monoterpene mixing ratios and was generally higher during the daytime compared to the night. As illustrated in a wind rose in the Supplement (Fig. S3b), $k^{\mathrm{NO}_{3}}$ displayed no clear dependence on wind directions. A closer examination of the data reveals that the nights can be roughly divided into two types: On 15 of the 34 nights, $\mathrm{NO}_{3}$ reactivities remained well above the instrument's LOD of $0.006 \mathrm{~s}^{-1}$ (from now on defined as "Type-1" nights), whereas during 14 nights $k^{\mathrm{NO}_{3}}$ was predominantly lower than $0.006 \mathrm{~s}^{-1}$ ("Type-2"). The other 5 nights showed a transitional behaviour between those two types.

An example of a Type-1 night is shown in Fig. 2a. Following a late evening value of $k^{\mathrm{NO}_{3}} \sim 0.1 \mathrm{~s}^{-1}$ the $\mathrm{NO}_{3}$ reactivity decreased during darkness from $0.08 \mathrm{~s}^{-1}$ at 20:00 UTC to $0.02 \mathrm{~s}^{-1}$ at 03:00 UTC. During this period, northerly winds with speeds around

$2104 \mathrm{~m} \mathrm{~s}^{-1}$ prevailed and the decrease in reactivity cannot be related to a change in air-mass origin. At the same time, we observed a decrease in temperature $\left(\sim 17\right.$ to $\left.\sim 13{ }^{\circ} \mathrm{C}\right)$ that was accompanied by an increase in the relative humidity (78 to $\left.98 \%\right)$ and a quasi-continuous reduction in $\mathrm{O}_{3}$ mixing ratios from $\sim 35$ to $\sim 25 \mathrm{ppbv}$. Note that ca. 20-30 pptv of $\mathrm{NO}$ were detected during this night, implying that reaction $\mathrm{R} 7$ would represent a significant loss process for $\mathrm{NO}_{3}$. A detailed discussion of this aspect follows in section 3.4 .

215 Figure $2 \mathrm{~b}$ shows an example of a Type-2 night with a sharp decrease of $k^{\mathrm{NO}_{3}}$ from $\sim 0.02 \mathrm{~s}^{-1}$ just before sunset to below the $\operatorname{LOD}\left(0.006 \mathrm{~s}^{-1}\right)$ within the first hour after sunset. As for Type-1, there is no significant change in the wind direction. However, in contrast to the Type- 1 example, after a slight increase just after sunset, $\mathrm{O}_{3}$ was roughly constant and significantly higher throughout the night with $\mathrm{NO}$ below the detection limit during the entire night. In addition the temperature $\left(14 \pm 1{ }^{\circ} \mathrm{C}\right)$ and relative humidity $(70 \pm 5 \%$ ) were roughly constant, the latter significantly lower than for the Type-1 example. 
Low $\mathrm{NO}_{3}$ reactivities at nighttime (i.e. Type-2 nights) can result from low rate of emission of biogenic VOCs (e.g. owing to low temperatures) but can also be associated with strong vertical gradients, which effectively decouple ground level emissions from the air above. For the latter case, we are dealing with a shallow surface layer with its top below the inlet, so that air is sampled from the nocturnal boundary or residual layer (Brown and Stutz, 2012) in which the $\mathrm{NO}_{3}$ lifetimes can be very long. This phenomenon has been reported for this and other mountain sites (Carslaw et al., 1997; Brown et al., 2016; Sobanski et al., 2016; Liebmann et al., 2017; Liebmann et al., 2018b). Slow exchange between the surface layer and the residual layer can result in strong gradients in trace gases such as $\mathrm{O}_{3}$, which undergoes dry-deposition in the surface layer but is long-lived in e.g. the residual layer. The situation for $\mathrm{NO}_{2}$ is more complex as it may be formed from the $\mathrm{O}_{3}$-induced oxidation of nearsurface emissions of $\mathrm{NO}$ and also lost via (slow) reaction with $\mathrm{O}_{3}$ and dry-deposition (Brown et al., 2003b; Stutz et al., 2004; Brown et al., 2007a).

230 Figure 3 displays the campaign-averaged diel cycles of $k^{\mathrm{NO}_{3}}$ (along with $\mathrm{O}_{3}, \mathrm{RH}, \mathrm{T}, \mathrm{NO}$ and MTs) classified according to Type-1 or Type-2 nights. $k^{\mathrm{NO}_{3}}$ was on average around $0.015 \mathrm{~s}^{-1}$, during Type-1 nights, with a daytime reactivity of $0.04 \mathrm{~s}^{-1}$ (Fig. 3a). The observed orders of magnitude for $k^{\mathrm{NO}_{3}}$ are consistent with the directly measured nighttime $\mathrm{NO}_{3}$ reactivities ranging between $<0.005$ and up to $0.06 \mathrm{~s}^{-1}$ during three nights in July 2015 (NOTOMO campaign) with the same instrument (Liebmann et al., 2017).

235 By definition, the median nighttime reactivity for Type-2 nights is at the instrument's LOD, while the median daytime reactivities prior to Type- 2 nights are very similar to those observed prior to Type-1 nights. The median diel cycles for $\mathrm{O}_{3}$ (Fig. 3b) differ significantly for the two types: during Type-1 nights $\mathrm{O}_{3}$ decreases continuously (consistent with previous observations on this site (Handisides, 2001)), while during Type-2 nights, $\mathrm{O}_{3}$ mixing ratios remain fairly constant and higher. There are also significant differences in the median NO mixing ratio, with nightime values (Fig. 3f) mostly below or close (10-

24012 pptv) to the LOD during Type-2 nights and values of 30-40 pptv during Type-1 nights.

The lower nighttime $k^{\mathrm{NO}_{3}}$ values observed during Type-2 nights compared Type-1 nights is accompanied by lower (factor 2.5) monoterpene mixing ratios (Fig. 3c). The median temperature during Type-2 nights are only up to $1 \mathrm{~K}$ colder than compared to Type-1 nights (Fig. 3d), which, based on the expression $\left(E_{M T} \propto \exp (\beta(T-297 K))\right.$ with $\beta=0.1 \mathrm{~K}^{-1}$, (Guenther et al., 1993)) results in a change of only $10 \%$ and is thus insufficient to explain the differences observed in $\Sigma$ MT on these nights.

With values of $85-95 \%$, the median relative humidity (Fig. 3e) was higher by around $5 \%$ (and increased continuously) during Type-1 nights, than for Type 2, for which a much smaller increase from 82 to $87 \%$ was observed.

In summary, in addition to very low $\mathrm{NO}_{3}$ reactivity, Type-2 nights are characterized by (1) larger and constant $\mathrm{O}_{3}$ mixing ratios, (2) lower but constant $\mathrm{RH}$, and (3) low concentrations of reactive trace gases like NO and monoterpenes. These observations support the presence of a very shallow surface layer with its top located below the tip of the inlet and decoupling of the sampled air from ground-level emissions (i.e. of $\mathrm{NO}$ and VOCs). Previous observations of strong gradients in $\mathrm{NO}_{3}$ mixing ratios and low reactivities have showed that decoupling of the air-mass from ground-level emissions can lead to $\mathrm{NO}_{3}$ lifetimes of up to hours (Allan et al., 2002; Brown et al., 2016; Sobanski et al., 2016). In order to test the hypothesis that low 
$\mathrm{NO}_{3}$ reactivities observed during Type-2 nights are the result of sampling from the nocturnal boundary layer (NBL), we mounted temperature and relative humidity sensors on a multi-copter drone to measure gradients in these parameters on the night of 22-23rd July, which is the same night as depicted in Fig. $2 b$.

The drone was located $\sim 20 \mathrm{~m}$ to the NE of the inlet, the starting height (ground level) was about $12 \mathrm{~m}$ lower than the top of the inlet. The drone flew a vertical profile with the first ascent/descent started before sunset at 18:30 UTC (blue dotted line, F1 in Fig. 2b) and a second after sunset at 20:20 UTC (red dotted line, F2 in Fig 2b). The flights were restricted to heights of $\sim 100 \mathrm{~m}$ above ground level owing to operational restrictions in the vicinity of Frankfurt airport.

The gradients in potential temperature $\theta$, for the two flights are shown in Fig. 4a. At 18:30 UTC (blue curve), the potential temperature increases gradually with altitude (positive stratification) as expected for a well-mixed boundary layer (Stull, 1988; Brown et al., 2007b). In contrast, the potential temperature gradient measured at 20:20 UTC reveals a strong increase in the first $3 \mathrm{~m}$, which represents the nocturnal surface layer. Above this, the potential temperature increases more slowly until ca.

$26520 \mathrm{~m}$ above the ground. This zone (shaded in red) represents the stable NBL above which the potential temperature is almost independent of height (neutral stratification), which is the typical behaviour of the residual layer (Stull, 1988; Brown et al., 2007b). The gradient in relative humidity (Fig. 4b) after sunset indicates a similar vertical structure with the top of the NBL characterized by a minimum in the relative humidity (Brown 2007b), also explaining why RH was, on average, lower during Type-2 compared to Type-1 nights (Fig. 3e). The approximate height of our inlet was situated ca. $10 \mathrm{~m}$ above the ground and the profile of $\theta$ implies that the air we sampled was from a NBL decoupled from ground-level emissions and in which vertical mixing is weak (Brown and Stutz, 2012). Under this scenario, NO originating from soil emissions and VOCs from plant emissions are trapped in the surface layer and only inefficiently entrained into the NBL. Unfortunately, owing to delays in obtaining permission to fly the drone, unfavourable weather conditions and other logistical considerations, these two flights on this one night are the only ones in which vertical profiles of temperature and RH were obtained. None-the-less, these observations provide important clues to how the meteorological situation can influence $\mathrm{NO}_{3}$ reactivity and $\mathrm{NO}$ levels at inlet height.

\subsection{Contribution of VOCs to $\mathrm{K}^{\mathrm{NO}_{3}}$}

As described above, $k^{\mathrm{NO}_{3}}$ includes the contribution of VOCs only and it is thus expected to correlate with the summed firstorder loss rates, $\Sigma k_{i}[\mathrm{VOC}]_{i}$ derived from the concentration $[\mathrm{VOC}]_{i}$ of each VOC and the corresponding rate constant $\left(k_{i}\right)$ for 280 its reaction with $\mathrm{NO}_{3}$, provided that all VOCs with a significant contribution were measured.

Unsaturated organic compounds (often of biogenic origin such as isoprene or terpenes) are generally the dominant reaction partners for $\mathrm{NO}_{3}$ in forested environments ( $\mathrm{Ng}$ et al., 2017). During TO2021, several hundreds of pptv of isoprene, monoterpenes and sesquiterpenes were detected during the second half of the campaign when VOC measurements became available (see Fig.1 and Fig.S4). Owing to their low rate coefficients (IUPAC, 2022), alkanes, aromatics and saturated, oxygenated species such as acetaldehyde, acetone and methanol were found to contribute negligibly to $k^{\mathrm{NO}_{3}}$. Consequently, 
only isoprene and the sum of mono- and sesquiterpenes are relevant for analysis. GC-MS measurements from a previous summer campaign at this site (Sobanski et al., 2017) derived fractional contributions to $\Sigma \mathrm{MT}$ of $50.5 \%, 28.9 \%$ and $20.6 \%$ for $\alpha$-pinene, limonene and myrcene, respectively. Using an accordingly weighted average of evaluated kinetic data (IUPAC, 2022), we derived an effective rate constant of $k=8.9 \times 10^{-12} \mathrm{~cm}^{3}$ molecule $\mathrm{s}^{-1}$ for $\mathrm{NO}_{3}+$ monoterpenes reactions at this site.

To calculate $\mathrm{NO}_{3}$ loss rates resulting from its reaction with sesquiterpenes, we used the IUPAC-recommended rate coefficient for $\mathrm{NO}_{3}+\beta$-caryophyllene. Neglecting the uncertainty associated with the assumption that the MT mixture was the same in both campaigns and combining the uncertainty in the measured VOC mixing ratios (20\%) and in the effective rate coefficient $(25 \%)$ leads to an overall fractional uncertainty of $33 \%$ in each term of $\Sigma k_{\mathrm{i}}[\mathrm{VOC}]_{\mathrm{i}}$.

In Fig. 5a we present a time-series of $k^{\mathrm{NO}_{3}}$ and $\mathrm{k}_{\mathrm{i}}[\mathrm{VOC}]_{\mathrm{i}}$. Clearly, $k^{\mathrm{NO}_{3}}$ and $\Sigma k_{\mathrm{i}}[\mathrm{VOC}]_{\mathrm{i}}$ agree within associated uncertainties most of the time. The poorer agreement observed around the $16^{\text {th }}$ July may have been related to the presence of fog and droplets in the sampling line and that around the $24^{\text {th }}$ July was most probably caused by conditioning effects when switching between flow-tubes. As indicated by the area in purple, the $\mathrm{NO}_{3}$ reactivity was almost entirely determined by the reaction with monoterpenes. Figure $5 \mathrm{~b}$ focusses on the Type-2 night previously shown in Fig. $2 \mathrm{~b}$ (but all $k^{\mathrm{NO}_{3}}<$ LOD set to $0.006 \mathrm{~s}^{-1}$ ) suspected to be impacted by a boundary layer effect. Within associated uncertainties, the VOC measurements confirm that VOC-induced $\mathrm{NO}_{3}$ reactivities are close to or below $0.006 \mathrm{~s}^{-1}$ for this period. The average contribution of the VOCs to $\Sigma k_{\mathrm{i}}[\mathrm{VOC}]_{\mathrm{i}}$ is depicted in Fig. $5 \mathrm{c}$ and shows that $84 \%$ of the overall reactivity is caused by monoterpenes, while isoprene and sesquiterpenes contribute $7 \%$ and $9 \%$ respectively.

Figure 6 plots $\Sigma \mathrm{k}_{\mathrm{i}}[\mathrm{VOC}]_{\mathrm{i}}$ versus $k^{\mathrm{NO}_{3}}$ for which a bivariate regression yields a slope of $1.04 \pm 0.03(2 \sigma)$ and an intercept of $(6.6 \pm 0.4) \times 10^{-3} \mathrm{~s}^{-1}$. A slope close to unity suggests near closure for the $\mathrm{NO}_{3}$ reactivity budget while the intercept is the 305 equivalent to the reactivity caused for example by $27 \mathrm{pptv}$ of $\beta$-caryophyllene or an overestimation of NO by just $18 \mathrm{pptv}$. We recall however, that speciated monoterpenes were not measured in TO2021 and the effective rate constant was based on the (non-testable) assumption that the summertime monoterpene composition at this site has remained unchanged over the last 10 years. The true uncertainty associated with the slope is expected to be close to $30 \%$, suggesting that the very good agreement may be partially fortuitous. None-the-less, we can conclude that the vast majority of the reactivity measured directly results from $\mathrm{NO}_{3}+$ monoterpene interactions.

\subsection{Fractional contribution of VOCs to $\mathrm{NO}_{3}$ losses throughout the diel cycle}

The dominant, direct gas-phase loss of $\mathrm{NO}_{3}$ occurs via photolysis $\left(\mathrm{NO}_{3}\right)$ reaction with $\mathrm{NO}\left(k_{7}[\mathrm{NO}]\right)$ and reaction with VOCs $\left(k^{\mathrm{NO}_{3}}\right.$ ). Neglecting depositional losses of $\mathrm{NO}_{3}$, the fractional contribution $F$ of $k^{\mathrm{NO}_{3}}$ to the overall $\mathrm{NO}_{3}$ loss rate constant, $L_{\mathrm{NO}_{3}}$, is thus given by:

$315 F=\frac{k^{N O_{3}}}{L_{N O_{3}}}=\frac{k^{N_{3}}}{k^{N_{3}+J_{N O_{3}}+k_{7}[\mathrm{NO}]}}$ 
Based on measured $k^{\mathrm{NO}_{3}}$, [NO] and $J_{\mathrm{NO}_{3}}$ (calculated from actinic flux measurements), we calculated time dependent values of each loss process throughout the campaign. The resulting mean diel cycle of $F$ is depicted in Fig. 7.

During the daytime, photolysis and reaction with $\mathrm{NO}$ were the dominant loss processes for $\mathrm{NO}_{3}$, as expected. The fractional contribution of VOC-induced losses is low at noon ( 9\%) but increases to up to $30 \%$ in the afternoon. The $\mathrm{NO}_{\mathrm{X}}$ levels at this site are such that, between sunrise and sunset, reaction with $\mathrm{NO}$ is on average $( \pm 1 \sigma)$ the dominant loss process for $\mathrm{NO}_{3}(53 \pm$ $20 \%$ ), followed by photolysis $(31 \pm 19 \%)$ and reaction with VOCs $(16 \pm 15 \%)$. This non-negligible contribution of VOCs to the daytime losses of $\mathrm{NO}_{3}$ is in broad agreement with field measurements in a boreal forest in Finland and on top of the Hohenpeissenberg mountain, where values of $\sim 20 \%$ were reported (Liebmann et al., 2018a; Liebmann et al., 2018b). This underlines that $\mathrm{NO}_{3}$, often considered to be important only at night, also contributes to the oxidation of BVOC during the day and thus potentially to the formation of organic nitrates (in competition to $\mathrm{OH}$ - and $\mathrm{O}_{3}$-initiated oxidation) throughout the diel cycle for example (Liebmann et al., 2019; Foulds et al., 2021).

At nighttime, in the absence of actinic radiation (to convert $\mathrm{NO}_{2}$ to $\mathrm{NO}$ ) and local anthropogenic emissions, NO levels are generally suppressed by reaction with $\mathrm{O}_{3}$. Fig. 7 reveals that $50-60 \%$ of $\mathrm{NO}_{3}$ was lost via reaction with VOCs at nighttime during TO2021, the remaining fraction reacting with $\mathrm{NO}(\mathrm{R} 7)$. The contribution of $\mathrm{NO}$ to the nighttime $\mathrm{NO}_{3}$ reactivity is larger than previously observed with the $k^{\mathrm{NO}_{3}}$-FT-CRDS instrument where reaction with VOCs was identified as the only significant loss process (Liebmann et al., 2018a; Liebmann et al., 2018b). A significant average contribution from NO is readily understood when one considers the large rate coefficient for reaction with $\mathrm{NO}_{3}\left(k_{7}=1.8 \times 10^{-11} \mathrm{~cm}^{3}\right.$ molecule $\mathrm{s}^{-1}$ at $298 \mathrm{~K}$ (IUPAC, 2022)) and NO mixing ratios well above the detection limit on many nights. Fig. 8 reveals a large night-to-night variability in the NO mixing ratio with minimum values close to the detection limit and maxima $>80 \mathrm{pptv}$. In the absence of local anthropogenic sources, soil emissions constitute the most likely source of NO at this site. Assuming that reaction with $\mathrm{O}_{3}$ represents the only NO loss process, and that stationary state as in Eq. 3 is achieved (a valid assumption as the lifetime of $\mathrm{NO}$ is only a few minutes in the presence of $20-40 \mathrm{ppbv}$ of $\left.\mathrm{O}_{3}\right) \mathrm{NO}$ emission rates $\left(E_{N O}\right)$ of 0.18 to $0.47 \mathrm{pptv} \mathrm{s}^{-1}$ are necessary to reproduce the observed nighttime NO mixing ratio within a surface layer of $10 \mathrm{~m}$ height.

$E_{N O}=[N O] \cdot k_{1}\left[O_{3}\right]$

In the absence of measurements of NO soil emission fluxes at the site and recognising that that these are highly dependent on temperature, season, soil humidity and degree of fertilization (Pilegaard, 2013), we take an annual mean NO emission flux of $1 \mathrm{~kg} \mathrm{ha}^{-1} \mathrm{yr}^{-1}$ for temperate, uncultivated grassland (Ludwig et al., 2001) to derive (assuming the same layer height of $10 \mathrm{~m}$ ) an NO emission rate of $0.27 \mathrm{pptv} \mathrm{s}^{-1}$, which lies within the range quoted above. As the summit of the Kleiner Feldberg is covered with blueberry bushes and surrounded by coniferous forest and that soils impacted from blueberry plants or spruce can support higher NO net fluxes than grass-covered soils (Bargsten et al., 2010), significant NO soil emissions at the summit of the Kleiner Feldberg appear to be plausible. Figure 8 also reveals that the highest levels of NO observed at $10 \mathrm{~m}$ height occur when $\mathrm{O}_{3}$ values are lowest. Anti-correlated $\mathrm{NO}$ and $\mathrm{O}_{3}$ mixing ratios are often observed when plumes of freshly emitted $\mathrm{NO}$ is mixed into aged air masses containing $\mathrm{O}_{3}$ and is a result of reaction $\mathrm{R} 1$ which converts $\mathrm{NO}$ to $\mathrm{NO}_{2}$. For our observations at $10 \mathrm{~m}$ height, chemistry (temperature dependent kinetics), boundary layer dynamics (extent of mixing/decoupling of surface 
layer and NBL) and plant physiology (emission rates of NO) may all contribute to the extent to which $\mathrm{NO}$ and $\mathrm{O}_{3}$ react. As the large night-to-night variability in the NO mixing ratios cannot be explained by temperature-dependent changes in the rate coefficient $k_{1}$ or in the emission rate of $\mathrm{NO}$, we conclude that boundary layer effects dominate and that the height of the surface layer and the degree to which NO is entrained from the surface layer into the NBL are the main controlling factors. We consider two limiting cases: 1) When the top of the nocturnal surface layer is above the inlet, and mixing is sufficient to homogenize the air within the first $10 \mathrm{~m}$ above the ground, $\mathrm{NO}$ originating from the soil can react with $\mathrm{O}_{3}$ via $\mathrm{R} 1$ (Aneja et al., 2000). This would correspond to observations during Type-1 nights. 2) When the surface-layer is less than $10 \mathrm{~m}$ deep and is decoupled from the NBL, soil emitted NO is not sampled by the inlet (ca. $10 \mathrm{~m}$ above the ground) and the measured NO mixing ratios are at the instrument's LOD. In this case, levels of $\mathrm{O}_{3}$ in the NBL remain high, as e.g. observed around 21 July. In reality, trace-gas gradients within the lowest layers will control the extent of mixing and case 1) will only operate when high wind speeds induce turbulent mixing close to the surface. We conclude that the variability in nighttime NO and the anti-correlation with $\mathrm{O}_{3}$ (see Fig. S5a) reflect rapid changes in boundary layer dynamics and vertical mixing within the lowest layers. Similarly high variability in $\mathrm{NO}_{3}$ mixing ratios has been attributed to a related phenomenon (Crowley et al., 2011). We note that if the time-scales over which boundary-layer dynamic change is less than the lifetime of NO, our steady-state assumption breaks down. None-the-less, the presence of up to $90 \mathrm{pptv}$ of $\mathrm{NO}$ at nighttime in the presence of 20-40 ppbv of $\mathrm{O}_{3}$ implies significant production of $\mathrm{NO}_{2}$.

We examined the nighttime generation of $\mathrm{NO}_{2}$ using box model calculations (FACSIMILE/CHEMCAT (Curtis and Sweetenham, 1987)) employing Reactions R1 to R4 and R7 with IUPAC-recommended, temperature-dependent rate coefficients ( $\mathrm{S} 5$ of the Supplement) and constrained by measurements of $\mathrm{NO}, \mathrm{O}_{3}$, ambient temperature and pressure. Known loss processes for $\mathrm{NO}_{2}$ at night are the slow reaction with $\mathrm{O}_{3}$ (to form $\mathrm{NO}_{3}$ ) and with $\mathrm{NO}_{3}$ to form $\mathrm{N}_{2} \mathrm{O}_{5}(\mathrm{R} 2-\mathrm{R} 4)$ and deposition to surfaces (e.g. foils, soil). Note that this simulation considers $\mathrm{R} 1$ as the only $\mathrm{NO}_{2}$ source and that it is only valid if chemistry and transport happen on a similar time scale.

Figure 9 plots the measured nighttime $\mathrm{NO}_{2}$ mixing ratios (black symbols) together with the model output using $v d_{\mathrm{NO} 2}=0.015$ $\mathrm{cm} \mathrm{s}^{-1}$ (which is based on a mean nighttime $\mathrm{NO}_{2}$ deposition for foliar surfaces (Delaria et al., 2018) and a value that is a factor 10 larger $\left(v d_{\mathrm{NO} 2}=0.15 \mathrm{~cm} \mathrm{~s}^{-1}\right)$ in both cases assuming a surface layer height of $10 \mathrm{~m}$ to derive loss rate constants of $1.5 \times 10^{-5}$

375 and $1.5 \times 10^{-4} \mathrm{~s}^{-1}$ respectively. Clearly, the larger deposition velocity is necessary to roughly align measured and simulated $\mathrm{NO}_{2}$ mixing ratios. Such large $\mathrm{NO}_{2}$ deposition velocities have previously been evoked in order to bring observed $\mathrm{NO}_{2}$ levels and NO emission rates into agreement (Jacob and Wofsy, 1990) and our average, nighttime deposition velocity of $0.15 \mathrm{~cm} \mathrm{~s}^{-1}$ is comparable to values of 0.1-0.57 $\mathrm{cm} \mathrm{s}^{-1}$ determined in boreal coniferous forests (Rondon et al., 1993) at night and $0.096 \mathrm{~cm}$ $\mathrm{s}^{-1}$ obtained in a temperate coniferous forest (Breuninger et al., 2013).

380 The interaction of $\mathrm{NO}_{2}$ with foliar surfaces, which can serve as both source and sink of $\mathrm{NO}_{2}$ is complex (Breuninger et al., 2013; Delaria et al., 2018) and a scenario in which the high (but variable) nighttime NO mixing ratios result from soil emissions while $\mathrm{NO}_{2}$ is simultaneously deposited on foliar surfaces is conceivable. Given that the stratification of the lowermost atmosphere at TO2021 was only examined on one night, and considering the likely variability in $\mathrm{NO}$ emission rates and $\mathrm{NO}_{2}$ 
deposition velocities (Ludwig et al., 2001; Ganzeveld et al., 2002), our interpretation of the nighttime $\mathrm{NO}$ and $\mathrm{NO}_{2}$ data remains speculative. Considering the lack of correlation between wind direction and abundance of nighttime NO (Fig. S5b), an alternative, point NO emission source (e.g. an NO bottle, or exhaust line) seems unlikely. Interferences by other trace-gases or reasons for bias of the CLD instrument could not be identified as causes for the high nocturnal levels of NO.

\section{5 $\mathrm{NO}_{3}$ mixing ratios}

During the TO2021 intensive, ambient $\mathrm{NO}_{3}$ mixing ratios were not monitored. However, as both the total $\operatorname{loss}$ term $L_{\mathrm{NO}_{3}}$ and

the production term $\left(P_{\mathrm{NO}_{3}}=\left(k_{2}\left[\mathrm{NO}_{2}\right]\left[\mathrm{O}_{3}\right]\right)\right)$ are known, we can derive $\mathrm{NO}_{3}$ mixing ratios by assuming that $\mathrm{NO}_{3}$ is in steadystate, i.e. that loss and production are balanced and the derivative of the $\mathrm{NO}_{3}$ mixing ratios is independent of time. Steady-state calculations of $\mathrm{NO}_{3}$ lifetimes or $\mathrm{NO}_{3}$ mixing ratios have been carried out in numerous studies (Platt et al., 1984; Geyer and Platt, 2002; Brown et al., 2011; Crowley et al., 2011; Liebmann et al., 2018a; Liebmann et al., 2018b) and have shown to be valid, when $\mathrm{NO}_{3}$ reactivities are high enough and the chemical equilibrium to $\mathrm{N}_{2} \mathrm{O}_{5}$ ( $\mathrm{R} 3$ and $\mathrm{R} 4$ ) is not perturbed by sudden changes in $\mathrm{NO}_{2}$ mixing ratios (Brown et al., 2003a; Dewald et al., 2020). Steady-state $\mathrm{NO}_{3}$ mixing ratios can be calculated with Eq. 4,

$\left[\mathrm{NO}_{3}\right]_{S S}=\frac{P_{\mathrm{NO}_{3}}}{L_{\mathrm{NO}}}=\frac{k_{2}\left[\mathrm{NO}_{2}\right]\left[\mathrm{O}_{3}\right]}{k^{\mathrm{NO}} \mathrm{O}_{3}+J_{\mathrm{NO}_{3}}+k_{7}[\mathrm{NO}]}$

which neglects both direct and indirect, heterogeneous loss of $\mathrm{NO}_{3}$ (R8 and R9). Previous estimates of the $\mathrm{NO}_{3}$ loss by aerosol uptake on the Kleiner Feldberg returned values of $\approx 0.001 \mathrm{~s}^{-1}$ or lower (Crowley et al., 2010; Phillips et al., 2016; Sobanski et 400 al., 2016) and are consequently insignificant compared to the average nighttime overall $\mathrm{NO}_{3}$ loss rate of $\approx 0.03 \mathrm{~s}^{-1}$.

Figure 10 displays a time-series of the calculated overal $\mathrm{NO}_{3}$ loss-constant, production rate and steady-state mixing ratios for TO2021. Nighttime $\mathrm{NO}_{3}$ losses vary typically between $<0.006 \mathrm{~s}^{-1}$ and $0.03 \mathrm{~s}^{-1}$, while the daytime losses were as large as 0.3 $\mathrm{s}^{-1}$. The $\mathrm{NO}_{3}$ production rate was, on average, close to $\sim 0.02 \mathrm{~s}^{-1}$ at nighttime, increasing to $0.1 \mathrm{~s}^{-1}$ during the day when $\mathrm{NO}_{2}$ and/or $\mathrm{O}_{3}$ mixing ratios were large. $\mathrm{NO}_{3}$ mixing ratios thus calculated are lower than about 6 pptv for all nights (one exception of 12 pptv on the $10^{\text {th }} \mathrm{July}$ ) and well below 2 pptv for most of the nights.

\subsubsection{Comparison with previous $\mathrm{NO}_{3}$ measurements at the Kleiner Feldberg}

$\mathrm{NO}_{3}$ measurements with which to compare the present data-set have been recorded at the Kleiner Feldberg during campaigns in 2008, 2011, 2012 and 2015 for which key details (including names and acronyms) are summarized in Tab.1: 
Table 1: Nighttime $\mathrm{NO}_{3}$ mixing ratios, median production rates and median nighttime loss rates at the top of the Kleiner Feldberg.

\begin{tabular}{|c|c|c|c|c|c|c|c|c|}
\hline Campaign & Reference & Period & $\begin{array}{l}\text { \# Nights } \\
\text { (< LOD) }\end{array}$ & $\begin{array}{c}\mathrm{P}_{\mathrm{NO}_{3}} \\
\text { pptv s }\end{array}$ & $\begin{array}{c}L_{N O_{3}} \\
10^{-3} \mathrm{~s}^{-1}\end{array}$ & $\begin{array}{l}\mathrm{NO}_{3} \\
\text { pptv }\end{array}$ & $\begin{array}{c}\mathrm{k} 8 \\
10^{-3} \mathrm{~s}^{-1}\end{array}$ & $\begin{array}{c}\mathrm{k} 9 \\
10^{-3} \mathrm{~s}^{-1}\end{array}$ \\
\hline TO2008 & Crowley et al, 2010 & May 2008 & $6(0)$ & 0.033 & $2.2^{\mathrm{b}}$ & $<\mathrm{LOD}-65^{\mathrm{a}}$ & 1.6 & $<0.2$ \\
\hline PARADE & Sobanski et al., 2016 & $\begin{array}{c}\text { Aug-Sep } \\
2011\end{array}$ & $21(4)$ & 0.044 & $4.5^{\mathrm{b}}$ & $<\mathrm{LOD}-250^{\mathrm{a}}$ & & 2 \\
\hline INUIT & This work & Aug 2012 & $16(4)$ & 0.049 & $3.7^{\mathrm{b}}$ & $<\mathrm{LOD}-190^{\mathrm{a}}$ & & \\
\hline NOTOMO & Sobanski et al., 2017 & Jul 2015 & $24(10)$ & 0.049 & $\begin{array}{c}7.5^{\mathrm{b}} \\
<5-40^{\mathrm{d}}\end{array}$ & $<\mathrm{LOD}-50^{\mathrm{a}}$ & & \\
\hline TO2021 & This work & Jul 2021 & $34(14)$ & 0.025 & $\begin{array}{c}27^{\mathrm{a}} \\
<6-40^{\mathrm{c}}\end{array}$ & $0-12^{\mathrm{b}}$ & & \\
\hline
\end{tabular}

Notes: \# Nights = Number of nights with measurements, the number in brackets represents the number of nights where either the $\mathrm{NO}_{3}$ mixing ratio or the directly measured value of $k^{\mathrm{NO}_{3}}$ was below the LOD. Direct (k8) and indirect (k9) loss rates of $\mathrm{NO}_{3}$ by heterogeneous uptake of $\mathrm{NO}_{3}$ and $\mathrm{N}_{2} \mathrm{O}_{5}$ were calculated only for TO2008 and PARADE. adirectly measured. ${ }^{\mathrm{b}}$ steady-state calculation. ${ }^{\mathrm{c}}$ directly measured; VOC contribution only. ${ }^{d}$ directly measured for 3 nights, no NO measurements available (Liebmann et al., 2017). TO2008 = Mini (un-named) campaign with only $\mathrm{NO}_{3}, \mathrm{NO}, \mathrm{O}_{3}$ and $\mathrm{NO}_{2}$ measurements. PARADE = PArticles and RAdicals: Diel observations of the impact of urban and biogenic Emissions, INUIT = Ice NUclei research UnIT, NOTOMO = NOcturnal chemistry at the Taunus Observatory: insights into Mechanisms and Oxidation.

The first measurements of $\mathrm{NO}_{3}$ (and $\mathrm{N}_{2} \mathrm{O}_{5}$ ) at the Kleiner Feldberg were performed on 6 nights in May 2008 (Crowley et al., 2010) (this data set is referred as TO2008), on 21 nights in July 2011 (PARADE campaign (Sobanski et al., 2016)), on 16 nights in August 2012 (INUIT campaign) and in September 2015 during the NOTOMO campaign (Liebmann et al., 2017; Sobanski et al., 2017). All previous $\mathrm{NO}_{3}$ data sets except for INUIT have been published. The time-series of the $\mathrm{NO}_{3}, \mathrm{NO}_{2}, \mathrm{O}_{3}$ mixing ratios (and resulting $P_{\mathrm{NO}_{3}}$ and $\mathrm{L}_{\mathrm{NO}_{3}}$ according to Eq. 4) from each of the campaigns used for this analysis are reproduced in the Supplement (S6, Fig. S6-S9) together with key features of the instruments used (Tab. S1).

425 The presence of nearby industrial centres imparts a strong wind-direction dependence on the composition of the air (and especially $\mathrm{NO}_{\mathrm{X}}$ ) at the Kleiner Feldberg with densely populated cities (and thus anthropogenic sources of $\mathrm{NO}_{\mathrm{x}}$ ) located in the SE and SW sectors. An overview of the prevailing wind directions and $\mathrm{NO}_{2}$ mixing ratios during each campaign are summarized in Fig. 11. The lowest, average $\mathrm{NO}_{2}$ mixing ratios were encountered during TO2008 (air arriving mainly from the East) and TO2021 which had a large contribution of air mases arriving from the North and West but almost none from the 430 Frankfurt area (SE-SSE). TO2021 is the only campaign with a significant contribution of air masses arriving from the "clean" Northern sector and the generally lower $\mathrm{NO}_{\mathrm{X}}$ levels during TO2021 may also have been a result of changes in vehicle usage in the region as a higher fraction of locally employed people worked from home as a result of the COVID-19 pandemic (Reifenberg et al., 2021). 
Figure 12 indicates that, in comparison to the previous summer campaigns (PARADE, INUIT and NOTOMO) the temperatures

were lower during TO2021 with the maximum value of $22{ }^{\circ} \mathrm{C}$ being $\sim 10^{\circ} \mathrm{C}$ lower than the maximum value during NOTOMO. TO2021 and PARADE had the highest incidence of very humid days, with a median RH of $>80 \%$ for TO2021 and $>75 \%$ for PARADE while for TO2008 the median relative humidity ( $51 \%)$ was the lowest.

For comparison of the nighttime $\mathrm{NO}_{3}$ mixing ratios, periods of daytime-nighttime transitions (when $\mathrm{NO}_{3}$ mixing ratios strongly change at sunrise or sunset) were excluded. The $\mathrm{NO}_{3}$ mixing ratios (lower panel), loss rates (middle panel) and production rates (upper panel) for each campaign are depicted in Fig.13 as a box-and-whisker plot. Note that nights on which the $\mathrm{NO}_{3}$ mixing ratios were $>0$ but below the instrument's LOD, were taken into account, whereas for the calculation of $L_{\mathrm{NO}_{3}}$ in the campaigns prior to $\mathrm{TO} 2021$, reactivities derived from $\mathrm{NO}_{3}$ mixing ratios below the LOD (i.e. $<1.5 \mathrm{pptv}$ ) were excluded from the analysis so that $L_{\mathrm{NO}_{3}}$ is not biased by values associated with high uncertainties.

Figure 13a shows that, during PARADE, INUIT and NOTOMO, the nighttime $\mathrm{NO}_{3}$ production rates were similar in terms of 445 both median values $\left(\sim 0.05 \mathrm{pptv} \mathrm{s}^{-1}\right)$ and range. Throughout these three campaigns, high production rates (above $\left.0.3 \mathrm{pptv} \mathrm{s}^{-1}\right)$ were occasionally observed, which for PARADE (Sobanski et al., 2016) were linked to winds originating from urban regions. Figure 13a also reveals that the median, nighttime $\mathrm{NO}_{3}$ production rates during PARADE, INUIT and NOTOMO were higher than during TO2008 and TO2021 (0.033 and $0.025 \mathrm{pptv} \mathrm{s}^{-1}$ ) which was driven by the lower $\mathrm{NO}_{2}$ mixing ratios in TO2008 and TO2021 for which air from the cleaner easterly and northerly sectors was encountered more frequently. Campaign-averaged diel cycles of $\mathrm{O}_{3}$ in the Supplement (Fig. S10) indicate that $\mathrm{O}_{3}$ during TO2008 and TO2021 were not substantially lower (even higher in the case of TO2008) than during PARADE, INUIT and NOTOMO.

Figure $13 \mathrm{~b}$ shows clearly that, with a median value of $0.028 \mathrm{~s}^{-1}$, the nighttime $\mathrm{NO}_{3}$ loss rates $\left(L_{\mathrm{NO}_{3}}\right)$ during TO2021 were significantly higher than for all other campaigns, which were $0.0075 \mathrm{~s}^{-1}$ for NOTOMO, $0.0045 \mathrm{~s}^{-1}$ for PARADE, $0.0037 \mathrm{~s}^{-1}$ for INUIT and $0.0022 \mathrm{~s}^{-1}$ for TO2008. A partial explanation for the greater $\mathrm{NO}_{3}$ loss term during TO2021 is found in the nighttime NO mixing ratios, which were significantly larger than those measured in e.g. TO2008 or PARADE. The effect of removing the contribution of $\mathrm{NO}$ reaction to $\mathrm{L}_{\mathrm{NO}_{3}}$ during PARADE (and TO2008) is minimal, as $\mathrm{NO}$ was close or below the LOD (4-10 pptv) on most nights (Crowley et al., 2010; Sobanski et al., 2016), which is confirmed by the corresponding campaign-averaged diel cycles of $\mathrm{NO}$ mixing ratios (Fig. S11). In contrast, subtraction of the contribution to $\mathrm{NO}_{3}$ reactivity of the high nighttime levels of $\mathrm{NO}$ observed during TO2021, would reduce $L_{\mathrm{NO}_{3}}$ to $\sim 0.011 \mathrm{~s}^{-1}$ (red, horizontal line in Fig. 13b) which is more comparable to that observed during e.g. NOTOMO and PARADE.

We note that, in general, the comparison of $\mathrm{NO}_{3}$ loss rates derived via the steady-state method and direct reactivity may be complicated by the fact that the steady-state method only works when $\mathrm{NO}_{3}$ is above the detection limit (often a result of low reactivity) whereas the direct measurement of $\mathrm{NO}_{3}$ losses performs best when reactivities are high. However, $\Sigma \mathrm{k}_{\mathrm{i}}[\mathrm{VOC}]_{\mathrm{i}}$ suggests that $L_{\mathrm{NO}_{3}}$ was never below $0.002 \mathrm{~s}^{-1}$ on Type-2 nights. As shown in the Supplement, setting values of $k^{\mathrm{NO}_{3}}<0.006$ $\mathrm{s}^{-1}$ to $0.002 \mathrm{~s}^{-1}$ would only occasionally lead to $\left[\mathrm{NO}_{3}\right]_{\mathrm{ss}}>10 \mathrm{pptv}$ (Fig. S12a) and thus only have a small impact on the distribution of $\mathrm{NO}_{3}$ mixing ratios (Fig. S12b), so that this bias cannot be fully responsible for the observed difference. 
None-the-less, Fig. 13a and 13b indicate that TO2021 was exceptional in that $P_{\mathrm{NO}_{3}}$ was the lowest of all campaigns at the Kleiner Feldberg while $L_{\mathrm{NO}_{3}}$ was the highest, which result in a calculated median $\mathrm{NO}_{3}$ mixing ratio of just 0.7 pptv. This contrasts greatly with median $\mathrm{NO}_{3}$ mixing ratios of 15, 10, 11 and 4 pptv observed during TO2008, PARADE, INUIT and NOTOMO (Fig. 13c) on the Kleiner Feldberg.

As alluded to above, this difference is partially caused by unusually high nighttime NO levels, but also results from the low $\mathrm{NO}_{3}$ production rate during TO2021. During PARADE, INUIT and NOTOMO, $\mathrm{NO}_{3}$ mixing ratios above 100 pptv were measured and linked to nights with exceptionally long $\mathrm{NO}_{3}$ lifetimes. For PARADE, this was suggested to be a result of sampling from above the surface layer, where $\mathrm{NO}_{3}$ lifetimes can be large owing to the decoupling from ground-level emissions (Brown et al., 2003b; Sobanski et al., 2016). While there is evidence for a similar situation for TO2021 on 21 Jul (Fig. 4), in the absence of vertically resolved meteorological data on the other nights, it is not clear whether purely meteorological effects are responsible for the observed low reactivities on 14 nights or whether reduced emission rates of reactive trace-gases additionally play a role. We are presently developing a drone-borne $\mathrm{NO}_{3}$ instrument to provide vertical gradients in $\mathrm{NO}_{3}$ (as well as $\mathrm{T}$ and $\mathrm{RH}$ ) in order to help resolve this issue.

\section{Summary and conclusions}

The fate of the $\mathrm{NO}_{3}$ radical at the summit of the Kleiner Feldberg during the TO2021 intensive in July 2021 was assessed with the help of direct $\mathrm{NO}_{3}$ reactivity and VOC measurements. Directly measured $\mathrm{NO}_{3}$ reactivities towards $\mathrm{VOCs}\left(\mathrm{NO}_{3}\right)$ were on average $\sim 0.011 \mathrm{~s}^{-1}$ at night and as large as $\sim 0.04 \mathrm{~s}^{-1}$ during the day. $\mathrm{NO}_{3}$ reactivities derived from $\mathrm{VOC}$ measurements showed an excellent agreement with $k^{\mathrm{NO}_{3}}$ throughout the diel cycle with VOC-induced $\mathrm{NO}_{3}$ losses by monoterpenes dominating with a contribution of $>80 \%$. Sesquiterpenes and isoprene contributed with $9 \pm 5 \%$ and $7 \pm 4 \%$, respectively.

During the daytime, $\mathrm{NO}$ removed on average $53 \pm 20 \%$ of the $\mathrm{NO}_{3}$, photolysis and reaction with VOCs contributed $\sim 31 \pm 19$ and $\sim 16 \pm 15 \%$ respectively. The daytime contribution of VOC-induced reactivity was highly variable and ranged from ca. $10 \%$ at noon to $30 \%$ in the afternoon implying that $\mathrm{NO}_{3}$ can contribute significantly e.g. to alkyl nitrate formation during daytime.

$490 k^{\mathrm{NO}_{3}}$ was predominantly below the LOD of $0.006 \mathrm{~s}^{-1}$ on 14 of the 34 nights. On one night, for which a vertical temperature and $\mathrm{RH}$ gradient were measured, the low $\mathrm{NO}_{3}$ reactivity was associated with reduced vertical mixing and the decoupling of a shallow surface layer from the layer above in which the trace-gas inlet was situated.

In the absence of direct measurements, $\mathrm{NO}_{3}$ mixing ratios during $\mathrm{TO} 2021$ were calculated from the total loss rate constant (VOCs, photolysis, $\mathrm{NO}$ ) and the $\mathrm{NO}_{3}$ production rate to enable comparison with directly measured $\mathrm{NO}_{3}$ mixing ratios during 495 four previous campaigns between 2008 and 2015 at the Kleiner Feldberg. For TO2021, $\mathrm{NO}_{3}$ loss rates were ca. a factor 3-5 higher than during previous campaigns while $\mathrm{NO}_{3}$ production rates were the lowest. Consequently, the calculated steady-state mixing ratios of $\mathrm{NO}_{3}$ are much lower than those directly measured during TO2008, PARADE and INUIT and NOTOMO. The exceptionally high nighttime $\mathrm{NO}_{3}$ loss rates during TO2021 are partially related to the presence of several tens of pptvs of NO, 
so that VOC-induced losses were 50-60\% of the overall loss term. This is in stark contrast to previous observations in forested environments where reactions with VOCs were the only relevant nighttime loss path of $\mathrm{NO}_{3}$. The observation of $\mathrm{NO}$ at levels of 20-80 pptv at nighttime in the presence of 30-40 ppbv of $\mathrm{O}_{3}$ imply large rates of $\mathrm{NO}_{2}$ formation. Constrained box-model calculations suggest that rapid losses of $\mathrm{NO}_{2}$ via e.g deposition would necessary in order to reproduce the observed nighttime $\mathrm{NO}_{2}$ mixing ratios. In order to confirm this hypothesis, measurements of $\mathrm{NO}$ emission and $\mathrm{NO}_{2}$ deposition rates on the Kleiner Feldberg under similar meteorological conditions are necessary.

Overall, the intercomparison of the $\mathrm{NO}_{3}$ mixing ratios and $\mathrm{NO}_{3}$ reactivity revealed high variability in data obtained over a long period on the same site and emphasizes that not only chemical effects but also boundary-layer dynamics and plantphysiological processes may have a great impact on observations.

Coda and Data Availability. Data of the TO2021 campaign is available upon request at https://keeper.mpdl.mpg.de/ to all scientists agreeing to the data protocol. The data of all other campaigns is available upon request from the corresponding author. The FACSIMILE code used for the box model can be found in the Supplement (S5).

Author contributions. $\mathrm{PD}$ measured $\mathrm{NO}_{3}$ reactivity and $\mathrm{NO}_{2}$ mixing ratios during $\mathrm{TO} 2021$, analysed the data and wrote the manuscript. JNC organized the TO2021 campaign, measured $\mathrm{NO}_{\mathrm{x}}$ and helped to revise the manuscript. CMN and HF provided

$515 \mathrm{NO}$ and $\mathrm{NO}_{2}$ data. AR, $\mathrm{AE}$ and JW provided VOC data. JNC and $\mathrm{CMN}$ provided $\mathrm{O}_{3}$ data. JS measured actinic fluxes and performed vertical profile measurements of temperature, relative humidity and pressure with the drone. All authors commented on the manuscript.

Competing interests. The authors declare that they have no conflict of interest.

\section{Acknowledgements.}

We thank Andreas Kürten and Joachim Curtius (Institute for Atmospheric and Environmental Sciences, Goethe University Frankfurt am Main) for logistical support and access to the facilities at the Taunus Observatory. We thank the DWD for the provision of meteorological data and Chemours for the FEP sample used to coat the flowtube reactors.

\section{References}

Allan, B. J., Carslaw, N., Coe, H., Burgess, R. A., and Plane, J. M. C.: Observations of the nitrate radical in the marine boundary layer, J. Atmos. Chem., 33, 129-154, doi:10.1023/A:1005917203307, 1999.

Allan, B. J., McFiggans, G., Plane, J. M. C., Coe, H., and McFadyen, G. G.: The nitrate radical in the remote marine boundary layer, J. 530 Geophys. Res.-Atmos., 105, 24191-24204, doi:10.1029/2000JD900314, 2000.

Allan, B. J., Plane, J. M. C., Coe, H., and Shillito, J.: Observations of $\mathrm{NO}_{3}$ concentration profiles in the troposphere, J. Geophys. Res.Atmos., 107, 4588, ACH11-1-ACH11-14, doi:10.1029/2002jd002112, 2002. 

Atmospheric Boundary Layer, Environ. Sci. Technol., 34, 2324-2329, doi:10.1021/es990997+, 2000. thick organic layer under different understory types, Biogeosciences, 7, 1425-1441, doi:10.5194/bg-7-1425-2010, 2010.

Bekö, G., Wargocki, P., Wang, N. J., Li, M. Z., Weschler, C. J., Morrison, G., Langer, S., Ernle, L., Licina, D., Yang, S., Zannoni, N., and Williams, J.: The Indoor Chemical Human Emissions and Reactivity (ICHEAR) project: Overview of experimental methodology and preliminary results, Indoor Air, 30, 1213-1228, doi:10.1111/ina.12687, 2020.

Boggs, P. T., Donaldson, J. R., Byrd, R. H., and Schnabel, R. B.: ODRPACK - Software for Weighted Orthogonal Distance Regression, ACM Trans. Math. Softw., 15, 348-364, doi:10.1145/76909.76913, 1989.

Breuninger, C., Meixner, F. X., and Kesselmeier, J.: Field investigations of nitrogen dioxide $\left(\mathrm{NO}_{2}\right)$ exchange between plants and the atmosphere, Atmos. Chem. Phys., 13, 773-790, doi:10.5194/acp-13-773-2013, 2013.

545 Brown, S. S., Stark, H., and Ravishankara, A. R.: Applicability of the steady state approximation to the interpretation of atmospheric observations of $\mathrm{NO}_{3}$ and $\mathrm{N}_{2} \mathrm{O}_{5}$, J. Geophys. Res.-Atmos., 108, 4539, ACH6-1-ACH6-10, doi:10.1029/2003JD003407, 2003a.

Brown, S. S., Stark, H., Ryerson, T. B., Williams, E. J., Nicks, D. K., Trainer, M., Fehsenfeld, F. C., and Ravishankara, A. R.: Nitrogen oxides in the nocturnal boundary layer: Simultaneous in situ measurements of $\mathrm{NO}_{3}, \mathrm{~N}_{2} \mathrm{O}_{5}, \mathrm{NO}_{2}, \mathrm{NO}$, and $\mathrm{O}_{3}$, J. Geophys. Res.-Atmos., 108, 4299, ACH18-1-ACH18-11, doi:10.1029/2002JD002917, 2003 b.

550 Brown, S. S., Dibb, J. E., Stark, H., Aldener, M., Vozella, M., Whitlow, S., Williams, E. J., Lerner, B. M., Jakoubek, R., Middlebrook, A. M., DeGouw, J. A., Warneke, C., Goldan, P. D., Kuster, W. C., Angevine, W. M., Sueper, D. T., Quinn, P. K., Bates, T. S., Meagher, J. F., Fehsenfeld, F. C., and Ravishankara, A. R.: Nighttime removal of $\mathrm{NO}_{\mathrm{x}}$ in the summer marine boundary layer, Geophys. Res. Lett., 31, L07108, 1-5, doi:10.1029/2004GL019412, 2004.

Brown, S. S., Dube, W. P., Osthoff, H. D., Stutz, J., Ryerson, T. B., Wollny, A. G., Brock, C. A., Warneke, C., De Gouw, J. A., Atlas, E., 555 Neuman, J. A., Holloway, J. S., Lerner, B. M., Williams, E. J., Kuster, W. C., Goldan, P. D., Angevine, W. M., Trainer, M., Fehsenfeld, F. C., and Ravishankara, A. R.: Vertical profiles in $\mathrm{NO}_{3}$ and $\mathrm{N}_{2} \mathrm{O}_{5}$ measured from an aircraft: Results from the NOAA P-3 and surface platforms during the New England Air Quality Study 2004, J. Geophys. Res.-Atmos., 112, D22304, 1-17, doi:10.1029/2007JD008883, 2007a.

Brown, S. S., Dube, W. P., Osthoff, H. D., Wolfe, D. E., Angevine, W. M., and Ravishankara, A. R.: High resolution vertical distributions of $\mathrm{NO}_{3}$ and $\mathrm{N}_{2} \mathrm{O}_{5}$ through the nocturnal boundary layer, Atmos. Chem. Phys., 7, 139-149, doi:10.5194/acp-7-139-2007, 2007b.

560 Brown, S. S., Degouw, J. A., Warneke, C., Ryerson, T. B., Dube, W. P., Atlas, E., Weber, R. J., Peltier, R. E., Neuman, J. A., Roberts, J. M., Swanson, A., Flocke, F., McKeen, S. A., Brioude, J., Sommariva, R., Trainer, M., Fehsenfeld, F. C., and Ravishankara, A. R.: Nocturnal isoprene oxidation over the Northeast United States in summer and its impact on reactive nitrogen partitioning and secondary organic aerosol, Atmos. Chem. Phys., 9, 3027-3042, doi:10.5194/acp-9-3027-2009, 2009.

Brown, S. S., Dube, W. P., Peischl, J., Ryerson, T. B., Atlas, E., Warneke, C., de Gouw, J. A., Hekkert, S. t. L., Brock, C. A., Flocke, F.,

565 Trainer, M., Parrish, D. D., Feshenfeld, F. C., and Ravishankara, A. R.: Budgets for nocturnal VOC oxidation by nitrate radicals aloft during the 2006 Texas Air Quality Study, J. Geophys. Res.-Atmos., 116, D24305, 1-15, doi:10.1029/2011jd016544, 2011.

Brown, S. S., and Stutz, J.: Nighttime radical observations and chemistry, Chem. Soc. Rev., 41, 6405-6447, doi:10.1039/C2CS35181A, 2012.

Brown, S. S., Dube, W. P., Tham, Y. J., Zha, Q. Z., Xue, L. K., Poon, S., Wang, Z., Blake, D. R., Tsui, W., Parrish, D. D., and Wang, T.: 
Burkholder, J. B., Sander, S. P., Abbatt, J., Barker, J. R., Huie, R. E., Kolb, C. E., Kurylo, M. J., Orkin, V. L., Wilmouth, D. M., and Wine, P. H.: Chemical Kinetics and Photochemical Data for Use in Atmospheric Studies, Evaluation No. 18, JPL Publication 15-10, Jet Propulsion Laboratory, Pasadena, available at: http://jpldataeval.jpl.nasa.gov (last access: 4 January 2022), 2016.

Carslaw, N., Plane, J. M. C., Coe, H., and Cuevas, E.: Observations of the nitrate radical in the free troposphere at Izana de Tenerife, J. Geophys. Res.-Atmos., 102, 10613-10622, doi:10.1029/96JD03512, 1997.

Crowley, J. N., Schuster, G., Pouvesle, N., Parchatka, U., Fischer, H., Bonn, B., Bingemer, H., and Lelieveld, J.: Nocturnal nitrogen oxides at a rural mountain site in south-western Germany, Atmos. Chem. Phys., 10, 2795-2812, doi:10.5194/acp-10-2795-2010, 2010.

Crowley, J. N., Thieser, J., Tang, M. J., Schuster, G., Bozem, H., Hasaynali Beygi, Z., Fischer, H., Diesch, J.-M., Drewnick, F., Borrmann,

580 S., Song, W., Yassaa, N., Williams, J., Pöhler, D., Platt, U., and Lelieveld, J.: Variable lifetimes and loss mechanisms for $\mathrm{NO}_{3}$ and $\mathrm{N}_{2} \mathrm{O}_{5}$ during the DOMINO campaign: Contrast between marine, urban and continental air, Atmos. Chem. Phys., 11, 10863-10870, doi:10.5194/acp-11-10853-2011, 2011.

Crutzen, P. J., and Lelieveld, J.: Human impacts on atmospheric chemisty, Annu. Rev. Earth Planet. Sci., 29, 17-45, doi:10.1146/annurev.earth.29.1.17, 2001.

585 Curtis, A. R., and Sweetenham, W. P.: Facsimile, Atomic Energy Research Establishment, Report R-12805, Harwell Laboratory, Oxfordshire, UK, 1987.

Delaria, E. R., Vieira, M., Cremieux, J., and Cohen, R. C.: Measurements of $\mathrm{NO}$ and $\mathrm{NO}_{2}$ exchange between the atmosphere and Quercus agrifolia, Atmos. Chem. Phys., 18, 14161-14173, doi:10.5194/acp-18-14161-2018, 2018.

590 Dewald, P., Liebmann, J. M., Friedrich, N., Shenolikar, J., Schuladen, J., Rohrer, F., Reimer, D., Tillmann, R., Novelli, A., Cho, C. M., Xu, K. M., Holzinger, R., Bernard, F., Zhou, L., Mellouki, W., Brown, S. S., Fuchs, H., Lelieveld, J., and Crowley, J. N.: Evolution of NO 3 reactivity during the oxidation of isoprene, Atmos. Chem. Phys., 20, 10459-10475, doi:10.5194/acp-20-10459-2020, 2020.

Drewnick, F., Boettger, T., von der Weiden-Reinmueller, S. L., Zorn, S. R., Klimach, T., Schneider, J., and Borrmann, S.: Design of a mobile aerosol research laboratory and data processing tools for effective stationary and mobile field measurements, Atmos. Meas. Tech., 5, 14431457, doi:10.5194/amt-5-1443-2012, 2012.

Edwards, P. M., Aikin, K. C., Dube, W. P., Fry, J. L., Gilman, J. B., de Gouw, J. A., Graus, M. G., Hanisco, T. F., Holloway, J., Huber, G., Kaiser, J., Keutsch, F. N., Lerner, B. M., Neuman, J. A., Parrish, D. D., Peischl, J., Pollack, I. B., Ravishankara, A. R., Roberts, J. M., Ryerson, T. B., Trainer, M., Veres, P. R., Wolfe, G. M., Warneke, C., and Brown, S. S.: Transition from high- to low-NOx control of nighttime oxidation in the southeastern US, Nat. Geosci., 10, 490-495, doi:10.1038/Ngeo2976, 2017.

Foulds, A., Khan, M. A. H., Bannan, T. J., Percival, C. J., Lowenberg, M. H., and Shallcross, D. E.: Abundance of NO 3 Derived OrganoNitrates and Their Importance in the Atmosphere, Atmosphere, 12, doi:10.3390/atmos12111381, 2021.

Friedrich, N., Tadic, I., Schuladen, J., Brooks, J., Darbyshire, E., Drewnick, F., Fischer, H., Lelieveld, J., and Crowley, J. N.: Measurement of $\mathrm{NO}_{\mathrm{x}}$ and $\mathrm{NO}_{\mathrm{y}}$ with a thermal dissociation cavity ring-down spectrometer (TD-CRDS): instrument characterisation and first deployment, Atmos. Meas. Tech., 13, 5739-5761, doi:10.5194/amt-13-5739-2020, 2020.

Friedrich, N., Eger, P., Shenolikar, J., Sobanski, N., Schuladen, J., Dienhart, D., Hottmann, B., Tadic, I., Fischer, H., Martinez, M., Rohloff, R., Tauer, S., Harder, H., Pfannerstill, E. Y., Wang, N. J., Williams, J., Brooks, J., Drewnick, F., Su, H., Li, G., Cheng, Y. F., Lelieveld, J., and Crowley, J. N.: Reactive nitrogen around the Arabian Peninsula and in the Mediterranean Sea during the 2017 AQABA ship campaign, Atmos. Chem. Phys., 21, 7473-7498, doi:10.5194/acp-21-7473-2021, 2021.

Fry, J. L., Kiendler-Scharr, A., Rollins, A. W., Brauers, T., Brown, S. S., Dorn, H. P., Dube, W. P., Fuchs, H., Mensah, A., Rohrer, F., Tillmann, R., Wahner, A., Wooldridge, P. J., and Cohen, R. C.: SOA from limonene: role of $\mathrm{NO}_{3}$ in its generation and degradation, Atmos. Chem. Phys., 11, 3879-3894, doi:10.5194/acp-11-3879-2011, 2011. 
Fry, J. L., Draper, D. C., Barsanti, K. C., Smith, J. N., Ortega, J., Winkle, P. M., Lawler, M. J., Brown, S. S., Edwards, P. M., Cohen, R. C., and Lee, L.: Secondary Organic Aerosol Formation and Organic Nitrate Yield from $\mathrm{NO}_{3}$ Oxidation of Biogenic Hydrocarbons, Environ. Sci. Technol., 48, 11944-11953, doi:10.1021/es502204x, 2014.

Ganzeveld, L. N., Lelieveld, J., Dentener, F. J., Krol, M. C., Bouwman, A. J., and Roelofs, G. J.: Global soil-biogenic NO ${ }_{x}$ emissions and the role of canopy processes, J. Geophys. Res.-Atmos., 107, ACH8-1-CH8-21, doi:10.1029/2001jd001289, 2002.

620 Geyer, A., Alicke, B., Konrad, S., Schmitz, T., Stutz, J., and Platt, U.: Chemistry and oxidation capacity of the nitrate radical in the continental boundary layer near Berlin, J. Geophys. Res.-Atmos., 106, 8013-8025, doi:10.1029/2000JD900681, 2001.

Geyer, A., and Platt, U.: Temperature dependence of the $\mathrm{NO}_{3}$ loss frequency: A new indicator for the contribution of $\mathrm{NO}_{3}$ to the oxidation of monoterpenes and $\mathrm{NO}_{\mathrm{x}}$ removal in the atmosphere, J. Geophys. Res.-Atmos., 107, 4431, ACL8-1-ACL-8-12, doi:10.1029/2001JD001215, 2002.

625 Guenther, A. B., Zimmerman, P. R., Harley, P. C., Monson, R. K., and Fall, R.: Isoprene and Monoterpene Emission Rate Variability Model Evaluations and Sensitivity Analyses, J. Geophys. Res.-Atmos., 98, 12609-12617, doi:10.1029/93jd00527, 1993.

Hallquist, M., Wangberg, I., Ljungstrom, E., Barnes, I., and Becker, K. H.: Aerosol and product yields from $\mathrm{NO}_{3}$ radical-initiated oxidation of selected monoterpenes, Environ. Sci. Technol., 33, 553-559, doi:10.1021/es980292s, 1999.

630 Handisides, G. M.: The influence of peroxy radicals on ozone production, PhD thesis, Fachbereich Geowissenschaften, Johann Wolfgang Goethe Universität, Frankfurt am Main, 2001.

Heintz, F., Platt, U., Flentje, H., and Dubois, R.: Long-term observation of nitrate radicals at the tor station, Kap Arkona (Rugen), J. Geophys. Res.-Atmos., 101, 22891-22910, doi:10.1029/96JD01549, 1996.

635 IUPAC: Task Group on Atmospheric Chemical Kinetic Data Evaluation, edited by: Ammann, M., Cox, R.A., Crowley, J.N., Herrmann, H., Jenkin, M.E., McNeill, V.F., Mellouki, A., Rossi, M. J., Troe, J. and Wallington, T. J., available at: http://iupac.pole-ether.fr/index.html, last access: 4 January 2022.

Jacob, D. J., and Wofsy, S. C.: Budgets of Reactive Nitrogen, Hydrocarbons, and Ozone over the Amazon-Forest during the Wet Season, J. Geophys. Res.-Atmos., 95, 16737-16754, doi:10.1029/JD095iD10p16737, 1990.

640 Jordan, A., Haidacher, S., Hanel, G., Hartungen, E., Mark, L., Seehauser, H., Schottkowsky, R., Sulzer, P., and Mark, T. D.: A high resolution and high sensitivity proton-transfer-reaction time-of-flight mass spectrometer (PTR-TOF-MS), Int. J. Mass spectrom., 286, 122-128, doi: 10.1016/j.ijms.2009.07.005, 2009.

Krechmer, J., Lopez-Hilfiker, F., Koss, A., Hutterli, M., Stoermer, C., Deming, B., Kimmel, J., Warneke, C., Holzinger, R., Jayne, J., 645 Worsnop, D., Fuhrer, K., Gonin, M., and de Gouw, J.: Evaluation of a New Reagent-Ion Source and Focusing Ion-Molecule Reactor for Use in Proton-Transfer-Reaction Mass Spectrometry, Anal. Chem., 90, 12011-12018, doi:10.1021/acs.analchem.8b02641, 2018.

Lelieveld, J., Butler, T. M., Crowley, J. N., Dillon, T. J., Fischer, H., Ganzeveld, L., Harder, H., Lawrence, M. G., Martinez, M., Taraborrelli, D., and Williams, J.: Atmospheric oxidation capacity sustained by a tropical forest, Nature, 452, 737-740, doi:10.1038/nature06870, 2008.

Lelieveld, J., Gromov, S., Pozzer, A., and Taraborrelli, D.: Global tropospheric hydroxyl distribution, budget and reactivity, Atmos. Chem.

Phys., 16, 12477-12493, doi:10.5194/acp-16-12477-2016, 2016.

Lelieveld, J., Pozzer, A., Poschl, U., Fnais, M., Haines, A., and Munzel, T.: Loss of life expectancy from air pollution compared to other risk factors: a worldwide perspective, Cardiovasc. Res., 116, 1334-1334, doi:10.1093/cvr/cvaa073, 2020. 
Liebmann, J., Karu, E., Sobanski, N., Schuladen, J., Ehn, M., Schallhart, S., Quéléver, L., Hellen, H., Hakola, H., Hoffmann, T., Williams, J., Fischer, H., Lelieveld, J., and Crowley, J. N.: Direct measurement of $\mathrm{NO}_{3}$ radical reactivity in a boreal forest, Atmos. Chem. Phys., 2018, 3799-3815, doi:10.5194/acp-18-3799-2018, 2018a.

Liebmann, J. M., Muller, J. B. A., Kubistin, D., Claude, A., Holla, R., Plaß-Dülmer, C., Lelieveld, J., and Crowley, J. N.: Direct measurements of $\mathrm{NO}_{3}$-reactivity in and above the boundary layer of a mountain-top site: Identification of reactive trace gases and comparison with OH-reactivity, Atmos. Chem. Phys., 18, 12045-12059, doi:10.5194/acp-18-12045-2018, $2018 \mathrm{~b}$.

Liebmann, J., Sobanski, N., Schuladen, J., Karu, E., Hellen, H., Hakola, H., Zha, Q., Ehn, M., Riva, M., Heikkinen, L., Williams, J., Fischer, H., Lelieyeld, J., and Crowley, J. N.: Alkyl nitrates in the boreal forest: formation via the $\mathrm{NO}_{3-}, \mathrm{OH}_{-}$and $\mathrm{O}_{3}$-induced oxidation of biogenic volatile organic compounds and ambient lifetimes, Atmos. Chem. Phys., 19, 10391-10403, doi:10.5194/acp-19-10391-2019, 2019.

Ludwig, J., Meixner, F. X., Vogel, B., and Förstner, J.: Soil-air exchange of nitric oxide: An overview of processes, environmental factors and modeling studies, Biogeochemistry, 52, 225-257, doi:10.1023/A:1006424330555, 2001.

Martinez, M., Perner, D., Hackenthal, E. M., Kulzer, S., and Schutz, L.: NO 3 at Helgoland during the NORDEX campaign in October 1996, J. Geophys. Res.-Atmos., 105, 22685-22695, doi:10.1029/2000JD900255, 2000.

Ng, N. L., Brown, S. S., Archibald, A. T., Atlas, E., Cohen, R. C., Crowley, J. N., Day, D. A., Donahue, N. M., Fry, J. L., Fuchs, H., Griffin, 670 R. J., Guzman, M. I., Herrmann, H., Hodzic, A., Iinuma, Y., Jimenez, J. L., Kiendler-Scharr, A., Lee, B. H., Luecken, D. J., Mao, J., McLaren, R., Mutzel, A., Osthoff, H. D., Ouyang, B., Picquet-Varrault, B., Platt, U., Pye, H. O. T., Rudich, Y., Schwantes, R. H., Shiraiwa, M., Stutz, J., Thornton, J. A., Tilgner, A., Williams, B. J., and Zaveri, R. A.: Nitrate radicals and biogenic volatile organic compounds: oxidation, mechanisms, and organic aerosol, Atmos. Chem. Phys., 17, 2103-2162, doi:10.5194/acp-17-2103-2017, 2017.

Nussbaumer, C. M., Parchatka, U., Tadic, I., Bohn, B., Marno, D., Martinez, M., Rohloff, R., Harder, H., Kluge, F., Pfeilsticker, K., 675 Obersteiner, F., Zoger, M., Doerich, R., Crowley, J. N., Lelieveld, J., and Fischer, H.: Modification of a conventional photolytic converter for improving aircraft measurements of $\mathrm{NO}_{2}$ via chemiluminescence, Atmos. Meas. Tech., 14, 6759-6776, doi:10.5194/amt-14-6759-2021, 2021.

Phillips, G. J., Thieser, J., Tang, M. J., Sobanski, N., Schuster, G., Fachinger, J., Drewnick, F., Borrmann, S., Bingemer, H., Lelieveld, J., and Crowley, J. N.: Estimating $\mathrm{N}_{2} \mathrm{O}_{5}$ uptake coefficients using ambient measurements of $\mathrm{NO}_{3}, \mathrm{~N}_{2} \mathrm{O}_{5}, \mathrm{ClNO}_{2}$ and particle-phase nitrate, Atmos. Chem. Phys., 16, 13231-13249, doi:10.5194/acp-16-13231-2016, 2016.

Pilegaard, K.: Processes regulating nitric oxide emissions from soils, Philos. Trans. R. Soc., B, 368, 1-8, doi:10.1098/rstb.2013.0126, 2013.

Place, B. K., Delaria, E. R., and Cohen, R. C.: Leaf Stomatal Uptake of Alkyl Nitrates, Environ. Sci. Technol. Lett., 9, 186-190, doi:10.1021/acs.estlett.1c00793, 2022.

685 Platt, U. F., Winer, A. M., Biermann, H. W., Atkinson, R., and Pitts, J. N.: Measurement of Nitrate Radical Concentrations in Continental Air, Environ. Sci. Technol., 18, 365-369, doi:10.1021/es00123a015, 1984.

Pozzer, A., Zimmermann, P., Doering, U. M., van Aardenne, J., Tost, H., Dentener, F., Janssens-Maenhout, G., and Lelieveld, J.: Effects of business-as-usual anthropogenic emissions on air quality, Atmos. Chem. Phys., 12, 6915-6937, doi:10.5194/acp-12-6915-2012, 2012.

Present, P. S. R., Zare, A., and Cohen, R. C.: The changing role of organic nitrates in the removal and transport of $\mathrm{NO}_{\mathrm{x}}$, Atmos. Chem. Phys.,

Reifenberg, S. F., Martin, A., Kohl, M., Hamryszczak, Z., Tadic, I., Röder, L., Crowley, D. J., Fischer, H., Kaiser, K., Schneider, J., Dörich, R., Crowley, J. N., Tomsche, L., Marsing, A., Voigt, C., Zahn, A., Pöhlker, C., Holanda, B., Krüger, O. O., Pöschl, U., Pöhlker, M., Jöckel, P., Dorf, M., Schumann, U., Williams, J., Curtius, J., Harder, H., Schlager, H., Lelieveld, J., and Pozzer, A.: Impact of reduced emissions on direct and indirect aerosol radiative forcing during COVID-19 lockdown in Europe, Atmos. Chem. Phys. Discuss., 2021, 1-23, doi:10.5194/acp-2021-1005, 2021. 
Rollins, A. W., Browne, E. C., Min, K.-E., Pusede, S. E., Wooldridge, P. J., Gentner, D. R., Goldstein, A. H., Liu, S., Day, D. A., Russell, L. M., and Cohen, R. C.: Evidence for $\mathrm{NO}_{\mathrm{x}}$ Control over Nighttime SOA Formation, Science, 337, 1210-1212, doi:10.1126/science.1221520, 2012.

700 Rondon, A., Johansson, C., and Granat, L.: Dry Deposition of Nitrogen-Dioxide and Ozone to Coniferous Forests, J. Geophys. Res.-Atmos., 98, 5159-5172, doi:10.1029/92jd02335, 1993.

Sobanski, N., Tang, M. J., Thieser, J., Schuster, G., Pöhler, D., Fischer, H., Song, W., Sauvage, C., Williams, J., Fachinger, J., Berkes, F., Hoor, P., Platt, U., Lelieveld, J., and Crowley, J. N.: Chemical and meteorological influences on the lifetime of $\mathrm{NO}_{3}$ at a semi-rural mountain site during PARADE, Atmos. Chem. Phys., 16, 4867-4883, doi:10.5194/acp-16-4867-2016, 2016.

705 Sobanski, N., Thieser, J., Schuladen, J., Sauvage, C., Song, W., Williams, J., lelieveld, J., and Crowley, J. N.: Day- and Night-time Formation of Organic Nitrates at a Forested Mountain-site in South West Germany, Atmos. Chem. Phys., 17, 4115-4130, doi:10.5194/acp-17-41152017, 2017.

Stull, R. B.: Stable Boundary Layer: An Introduction to Boundary Layer Meteorology, edited by: Stull, R. B., Springer Netherlands, Dordrecht, 499-543, 1988.

710 Stutz, J., Alicke, B., Ackermann, R., Geyer, A., White, A., and Williams, E.: Vertical profiles of $\mathrm{NO}_{3}, \mathrm{~N}_{2} \mathrm{O}_{5}, \mathrm{O}_{3}$, and $\mathrm{NO}_{x}$ in the nocturnal boundary layer: 1. Observations during the Texas Air Quality Study 2000, J. Geophys. Res.-Atmos., 109, D12306, 1-14, doi:10.1029/2003JD004209, 2004.

Stutz, J., Wong, K. W., Lawrence, L., Ziemba, L., Flynn, J. H., Rappenglueck, B., and Lefer, B.: Nocturnal $\mathrm{NO}_{3}$ radical chemistry in Houston, TX, Atmos. Environ., 44, 4099-4106, doi:10.1016/j.atmosenv.2009.03.004, 2010.

715 Tadic, I., Crowley, J. N., Dienhart, D., Eger, P., Harder, H., Hottmann, B., Martinez, M., Parchatka, U., Paris, J. D., Pozzer, A., Rohloff, R., Schuladen, J., Shenolikar, J., Tauer, S., Lelieveld, J., and Fischer, H.: Net ozone production and its relationship to nitrogen oxides and volatile organic compounds in the marine boundary layer around the Arabian Peninsula, Atmos. Chem. Phys., 20, 6769-6787, doi:10.5194/acp-20-6769-2020, 2020.

Wayne, R. P., Barnes, I., Biggs, P., Burrows, J. P., Canosa-Mas, C. E., Hjorth, J., Le Bras, G., Moortgat, G. K., Perner, D., Poulet, G., 720 Restelli, G., and Sidebottom, H.: The nitrate radical: Physics, chemistry, and the atmosphere, Atmos. Environ., 25, 1, 1-206, doi:10.1016/0960-1686(91)90192-A, 1991.

Wennberg, P. O., Bates, K. H., Crounse, J. D., Dodson, L. G., McVay, R. C., Mertens, L. A., Nguyen, T. B., Praske, E., Schwantes, R. H., Smarte, M. D., St Clair, J. M., Teng, A. P., Zhang, X., and Seinfeld, J. H.: Gas-Phase Reactions of Isoprene and Its Major Oxidation Products, Chem. Rev., 118, 3337-3390, doi:10.1021/acs.chemrev.7b00439, 2018.

725 Wu, R., Vereecken, L., Tsiligiannis, E., Kang, S., Albrecht, S. R., Hantschke, L., Zhao, D., Novelli, A., Fuchs, H., Tillmann, R., Hohaus, T., Carlsson, P. T. M., Shenolikar, J., Bernard, F., Crowley, J. N., Fry, J. L., Brownwood, B., Thornton, J. A., Brown, S. S., Kiendler-Scharr, A., Wahner, A., Hallquist, M., and Mentel, T. F.: Molecular composition and volatility of multi-generation products formed from isoprene oxidation by nitrate radical, Atmos. Chem. Phys., 21, 10799-10824, doi:10.5194/acp-21-10799-2021, 2021.

730 York, D.: Least-Squares Fitting of a Straight Line, Can. J. Phys., 44, 1079-1086, doi:10.1139/p66-090, 1966. 


\section{Figures}

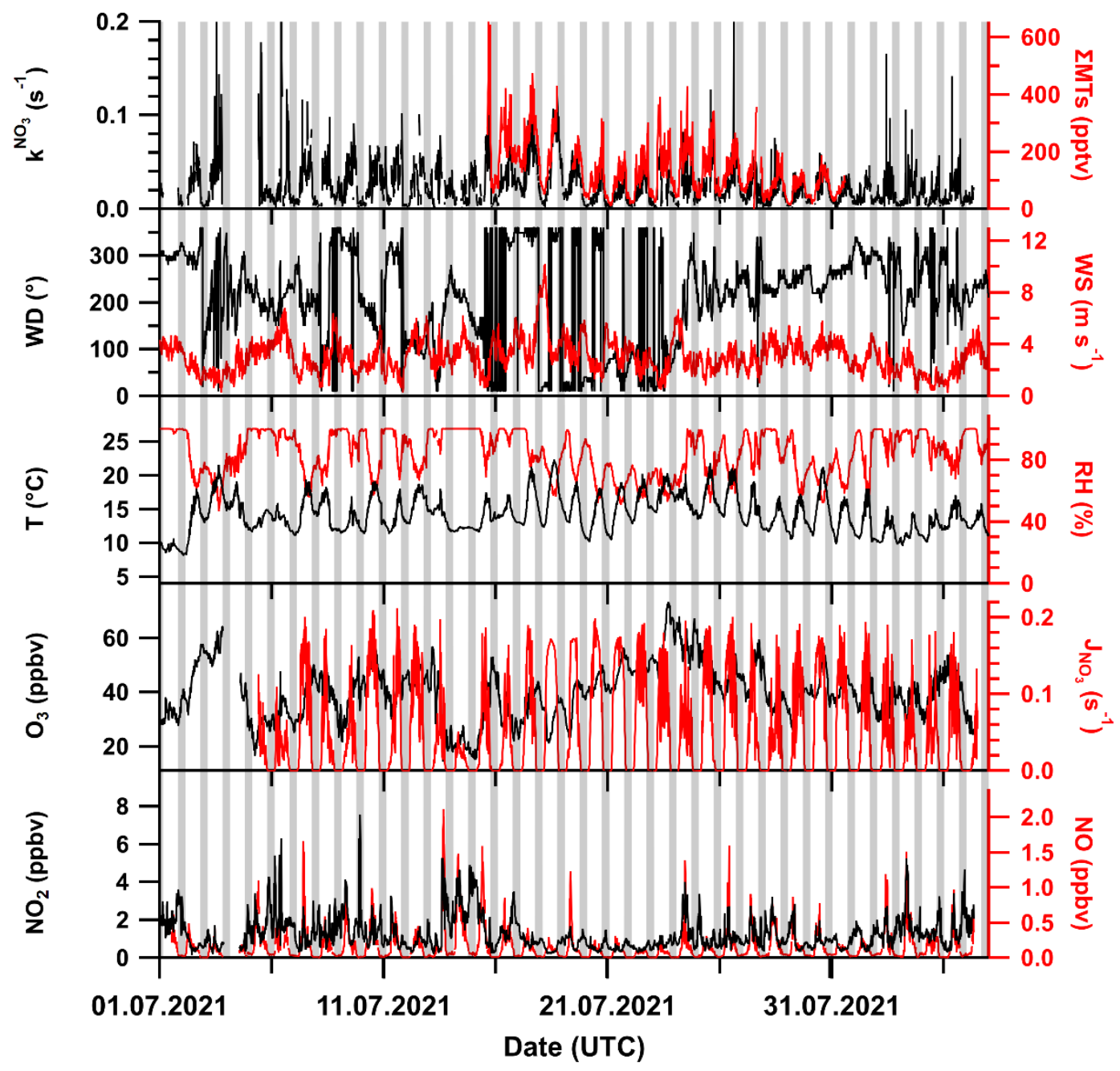

Figure 1: Overview of key measurements during the TO2021 campaign with wind direction (WD), temperature (T), sum of monoterpenes ( $\Sigma \mathrm{MT}$ ), wind speed (WS), relative humidity $(\mathrm{RH}), \mathrm{NO}_{3}$ photolysis rate coefficient $\left(\boldsymbol{J}_{\mathrm{NO}_{3}}\right)$. Meteorological data was provided by the German Meteorological Service (DWD). Nighttime periods are shaded grey. The x-axis ticks are at 00:00 UTC. 

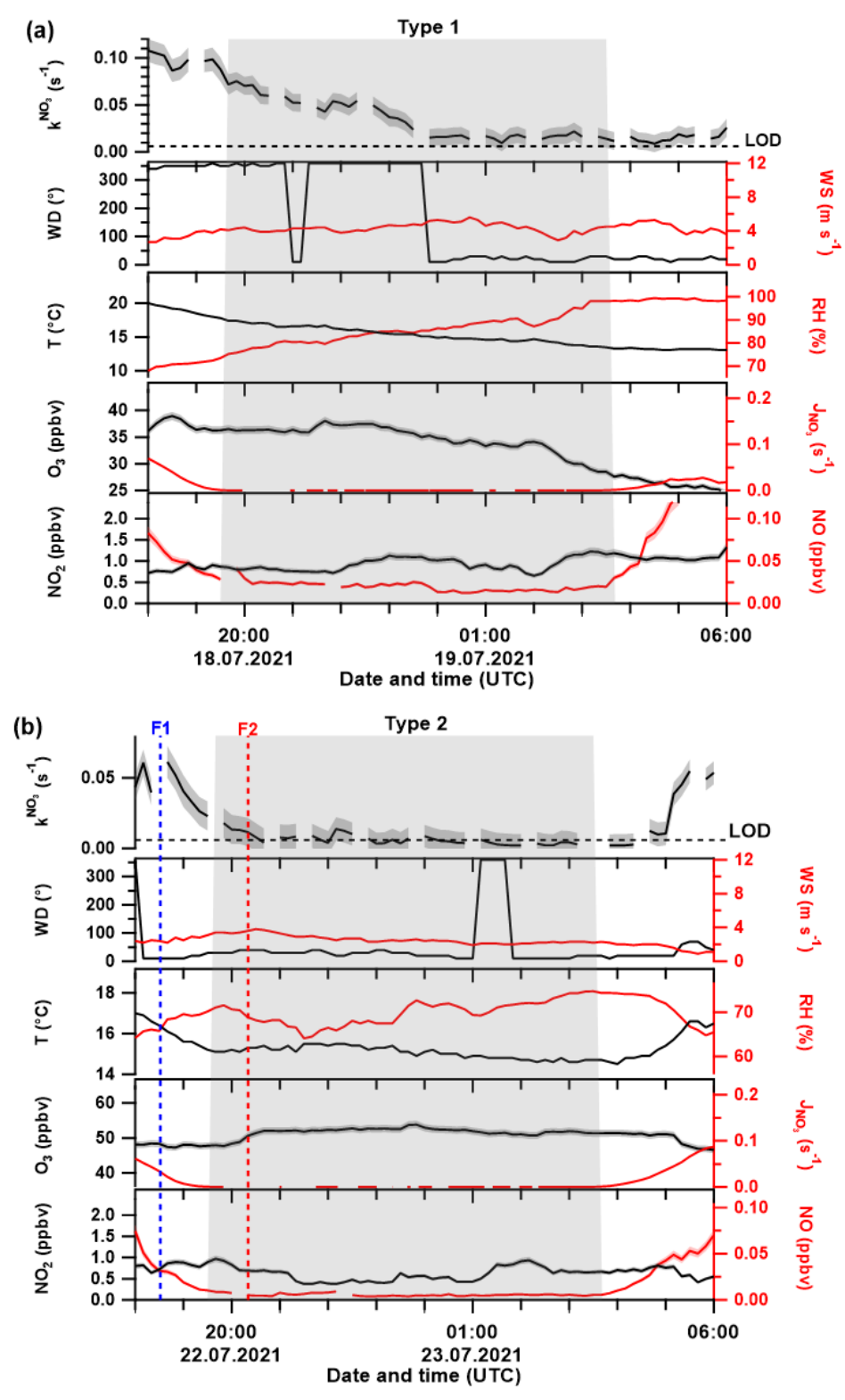

Figure 2: Time-series of directly measured $\mathrm{NO}_{3}$ reactivity $\left(\boldsymbol{k}^{N \boldsymbol{O}_{3}}\right)$ together with auxiliary measurements during Type-1 (a) and Type-2 nights night (b). F1 and F2 mark times at which drone-assisted temperature and relative humidity profiles wer measured. The grey-shaded area represents nighttime. Abbreviations are defined in caption of Fig.1. The shaded areas in the colour of the lines denotes the corresponding uncertainty of the measured parameter. 
https://doi.org/10.5194/acp-2022-163

Preprint. Discussion started: 7 March 2022

(c) Author(s) 2022. CC BY 4.0 License.
Atmospheric

Chemistry

and Physics

Discussions
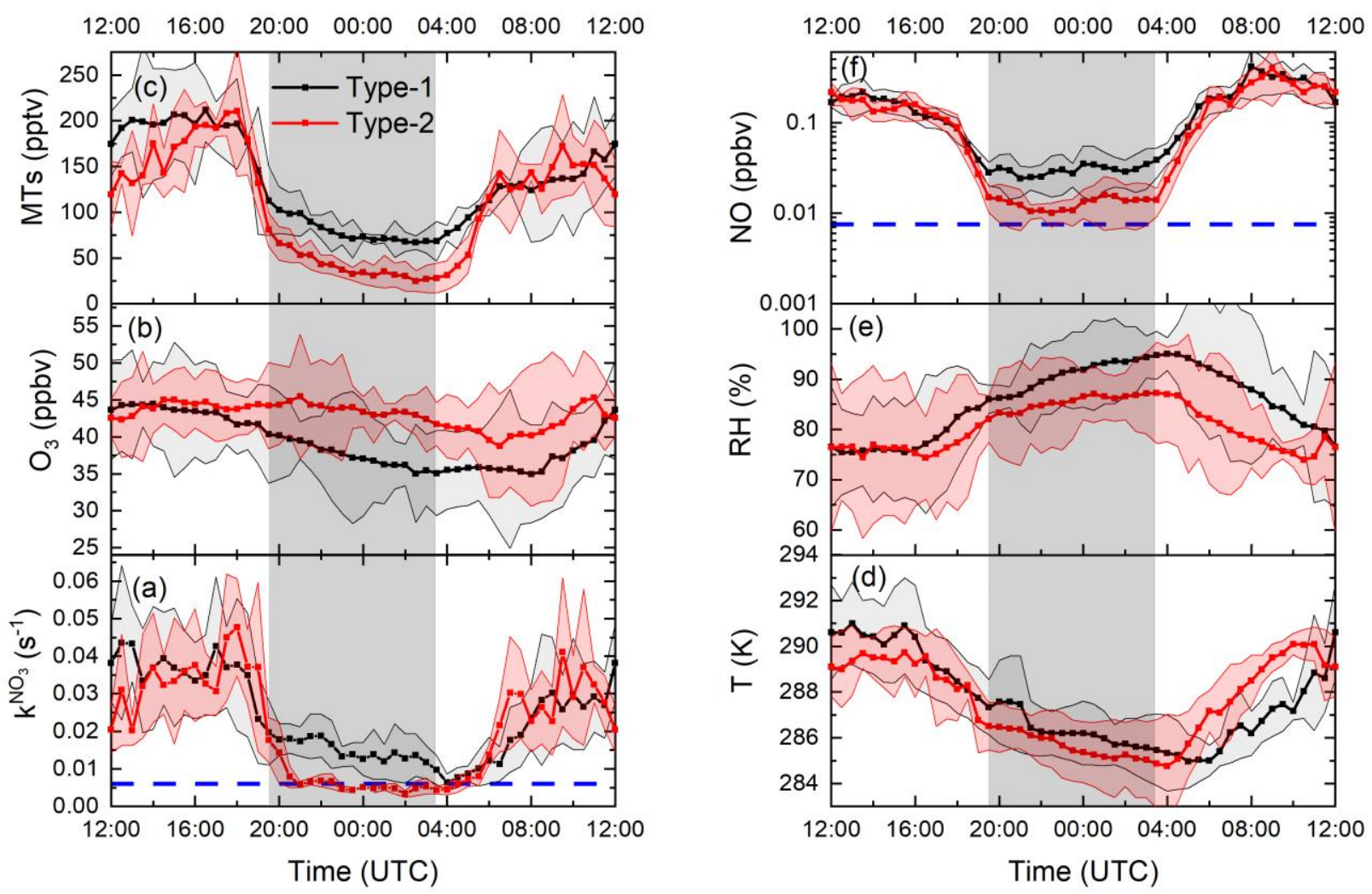

Figure 3: Median diel profiles of (a) directly measured $\mathrm{NO}_{3}$ reactivities, (b) $\mathrm{O}_{3}$ mixing ratios, (c) monoterpenes, (d) temperature, (e) relative humidity, and (f) NO mixing ratios classified by night types (Type-1 in black, Type-2 in red). The grey shaded area represents the nighttime period. The shaded areas in line colour represent the $25^{\text {th }}$ and $75^{\text {th }}$ percentiles. The blue lines denote the LODs of the instruments used to measure $\mathrm{NO}_{3}$ reactivity and $\mathrm{NO}$. 


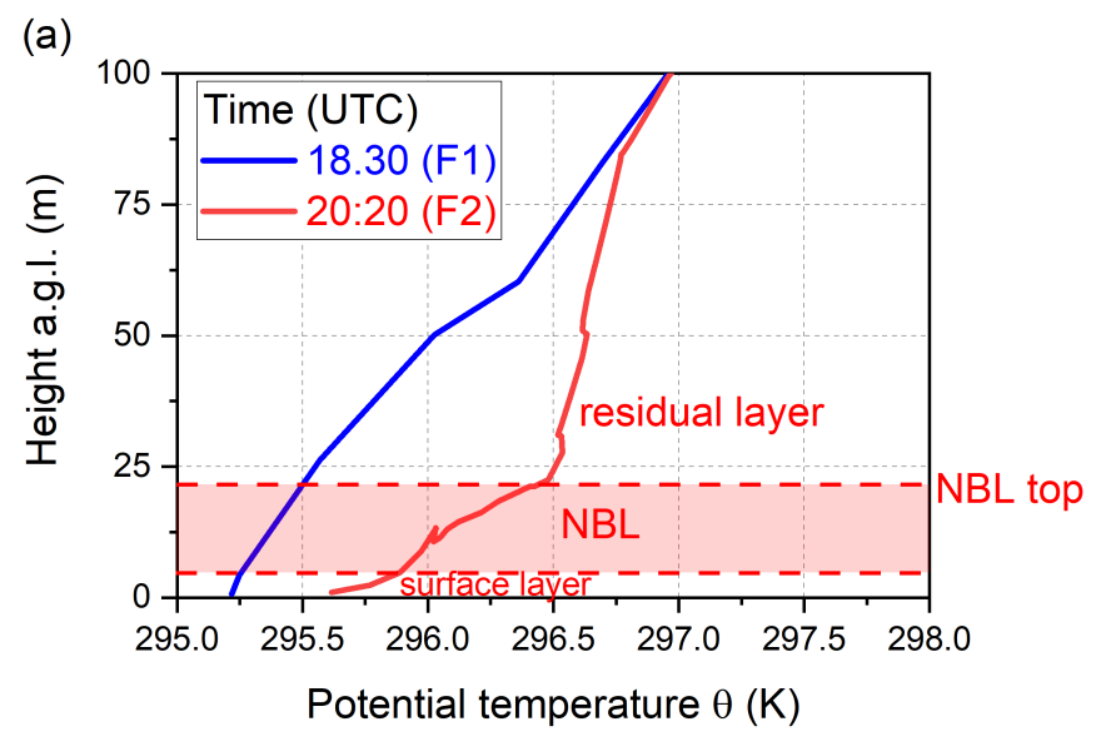

(b)

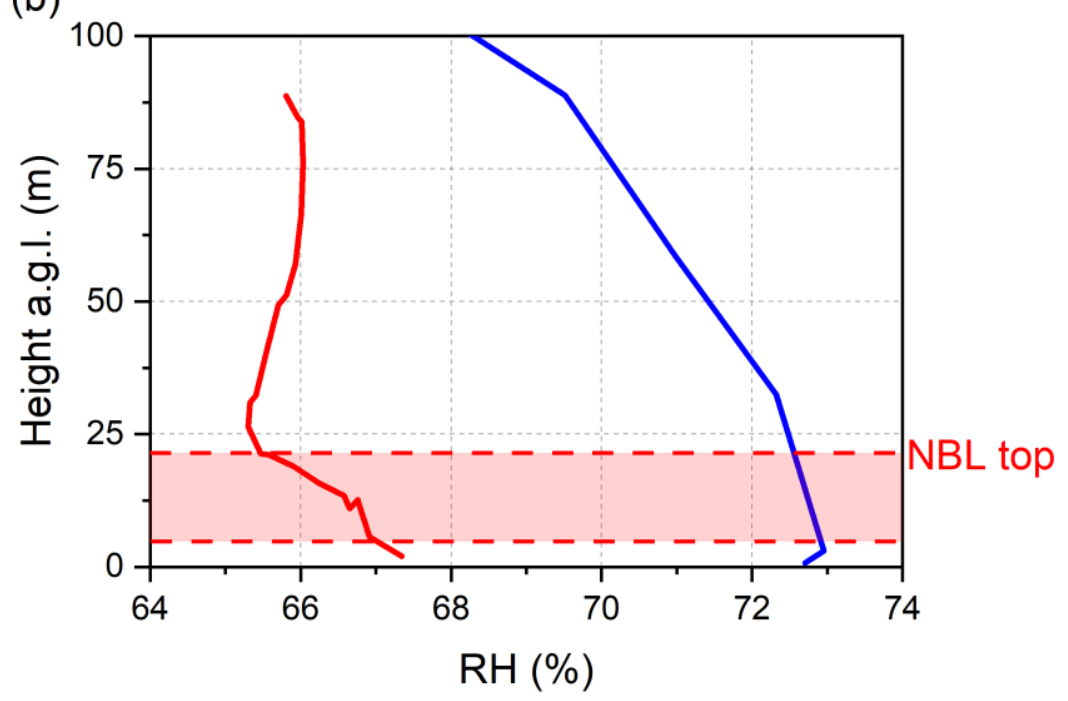

Figure 4: Vertical profiles of potential temperature (a) and relative humidity (b) at the summit of the Kleiner Feldberg at 18:30 UTC (blue) and 20:20 UTC (red). The nocturnal boundary layer (NBL) at 20:20 UTC is shaded red. 
https://doi.org/10.5194/acp-2022-163

Preprint. Discussion started: 7 March 2022

(C) Author(s) 2022. CC BY 4.0 License.
Atmospheric

Chemistry

and Physics

Discussions (a)

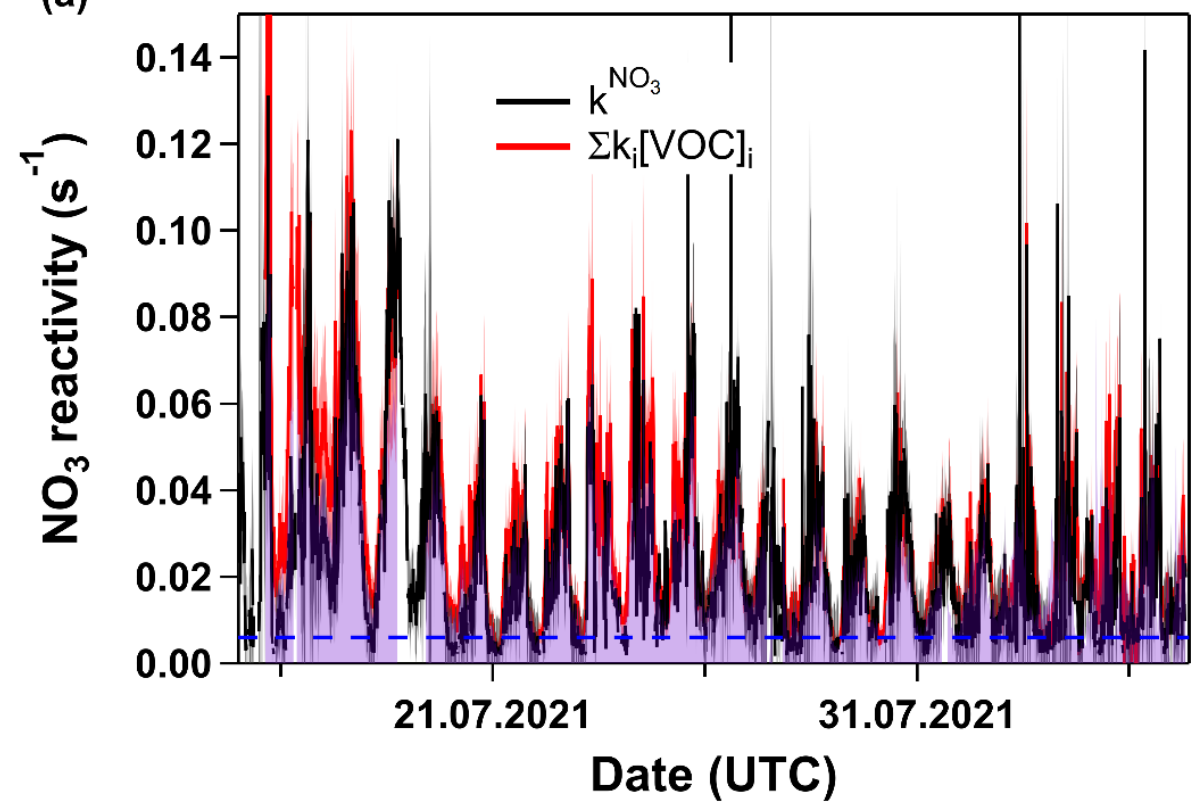

(b)

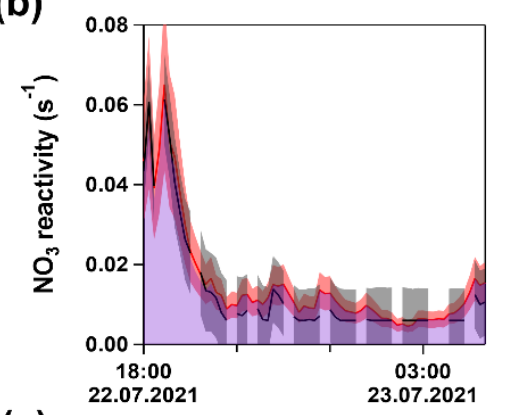

(c)

Date and time (UTC)

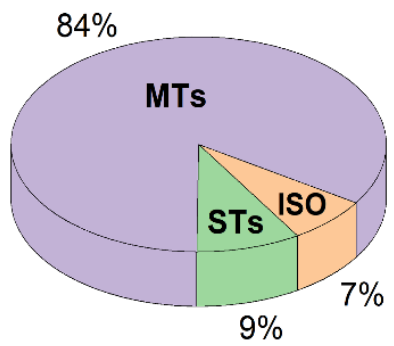

Figure 5: (a) Time-series of $\boldsymbol{k}^{\mathbf{N O}} \mathbf{3}_{3}$ and $\Sigma \mathrm{k}_{\mathrm{i}}[\mathrm{VOC}]_{\mathrm{i}}$. Dashed blue line marks the LOD of the $\boldsymbol{k}^{\mathbf{N \boldsymbol { O } _ { 3 }}}$ measurement. The purple shade represents the contribution of monoterpenes. (b) Same as (a) but with a detailed view of the night between the $22^{\text {nd }}$ and $23^{\text {rd }}$ July presented in Fig. $2 \mathrm{~b}$ (c) Pie-chart of fractional contributions of isoprene, monoterpenes and sesquiterpenes to $\Sigma k_{\mathrm{i}}[\mathrm{VOC}]_{\mathrm{i}}$ over this time period. 


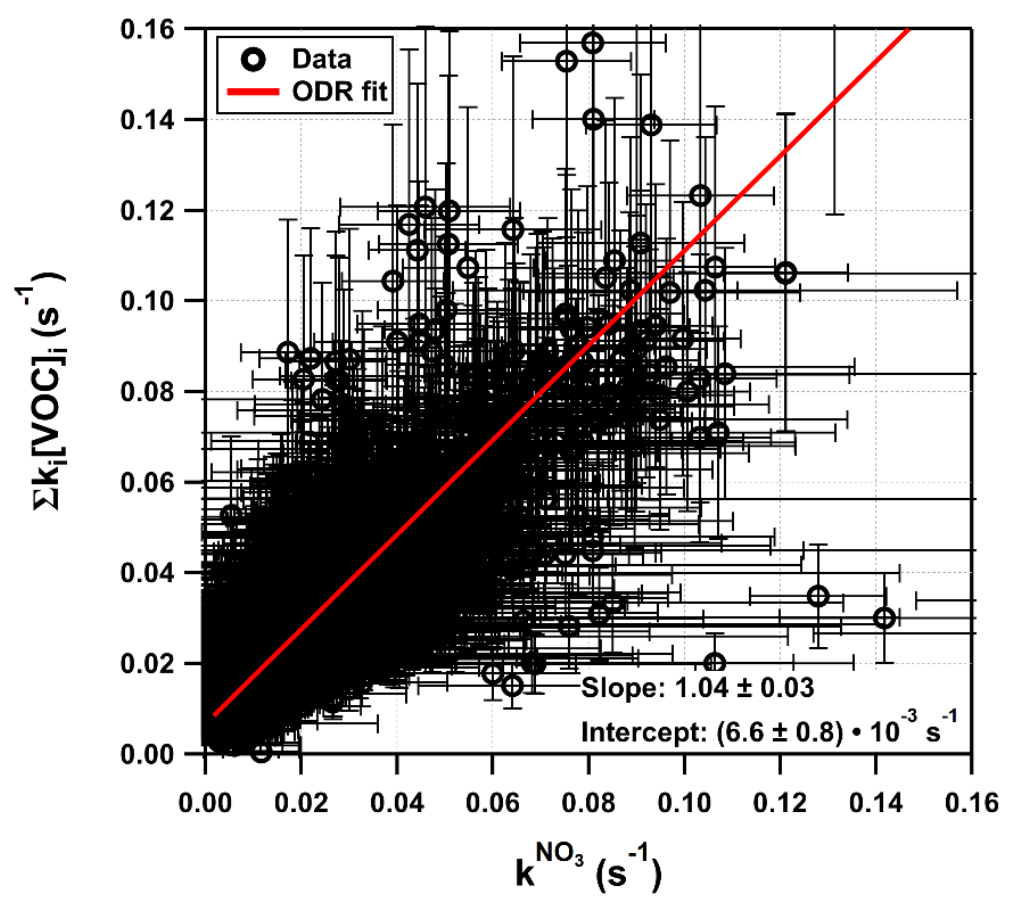

Figure 6: Plot of $k^{\mathrm{NO}_{3}}$ versus $\Sigma \mathrm{k}_{\mathrm{i}}[\mathrm{VOC}] \mathrm{i}$. The red solid line represents an orthogonal distance regression (ODR) with a slope of 1.04 and an intercept of $6.6 \times 10^{-3} \mathrm{~s}^{-1}$. 
https://doi.org/10.5194/acp-2022-163

Preprint. Discussion started: 7 March 2022

(c) Author(s) 2022. CC BY 4.0 License.

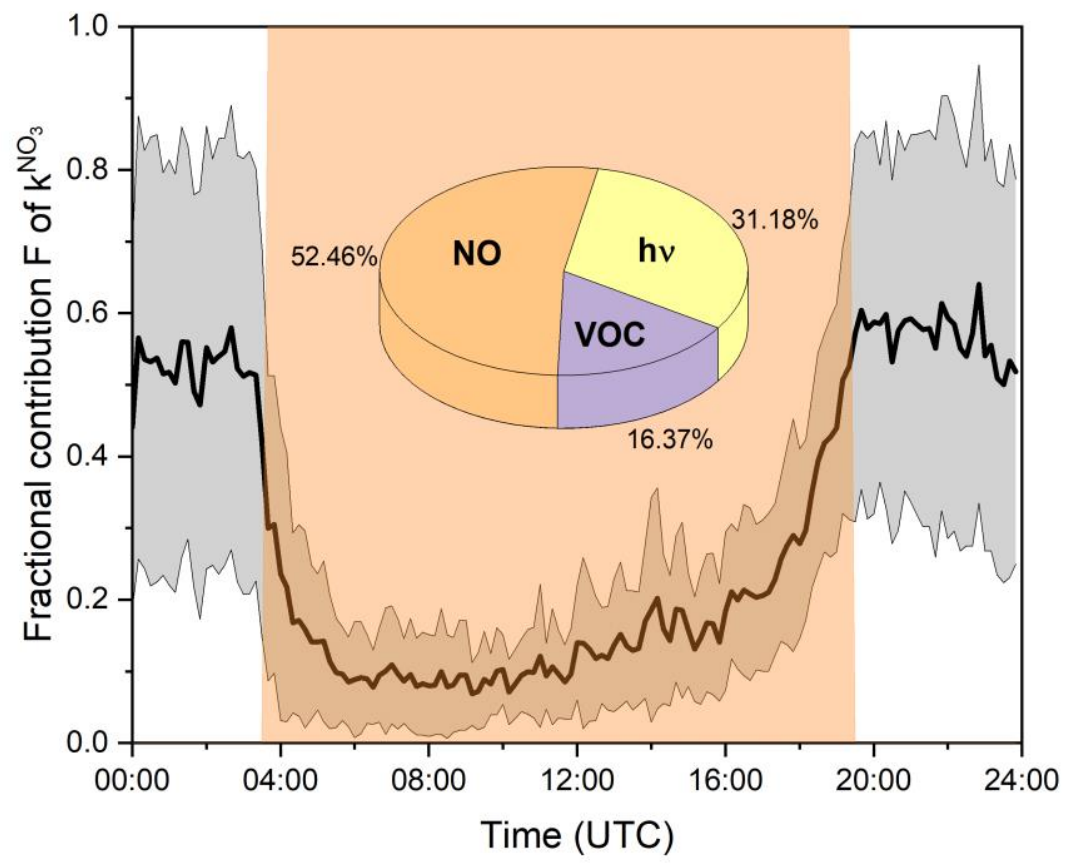

Figure 7: Mean, fractional contribution (F) of $\boldsymbol{k}^{\mathbf{N O}}{ }_{3}$ to the overall $\mathrm{NO}_{3}$ loss rate over the diel-cycle. The grey shaded area represents the standard deviation $(1 \sigma)$ of the mean values. Orange shaded area indicates daytime. The pie-chart shows the mean fractional contribution to $\mathrm{NO}_{3}$ loss of reaction with $\mathrm{NO}$, photolysis and reaction with VOCs during the daytime. 
https://doi.org/10.5194/acp-2022-163

Preprint. Discussion started: 7 March 2022

(c) Author(s) 2022. CC BY 4.0 License.

(c) (i)
Atmospheric

Chemistry

and Physics

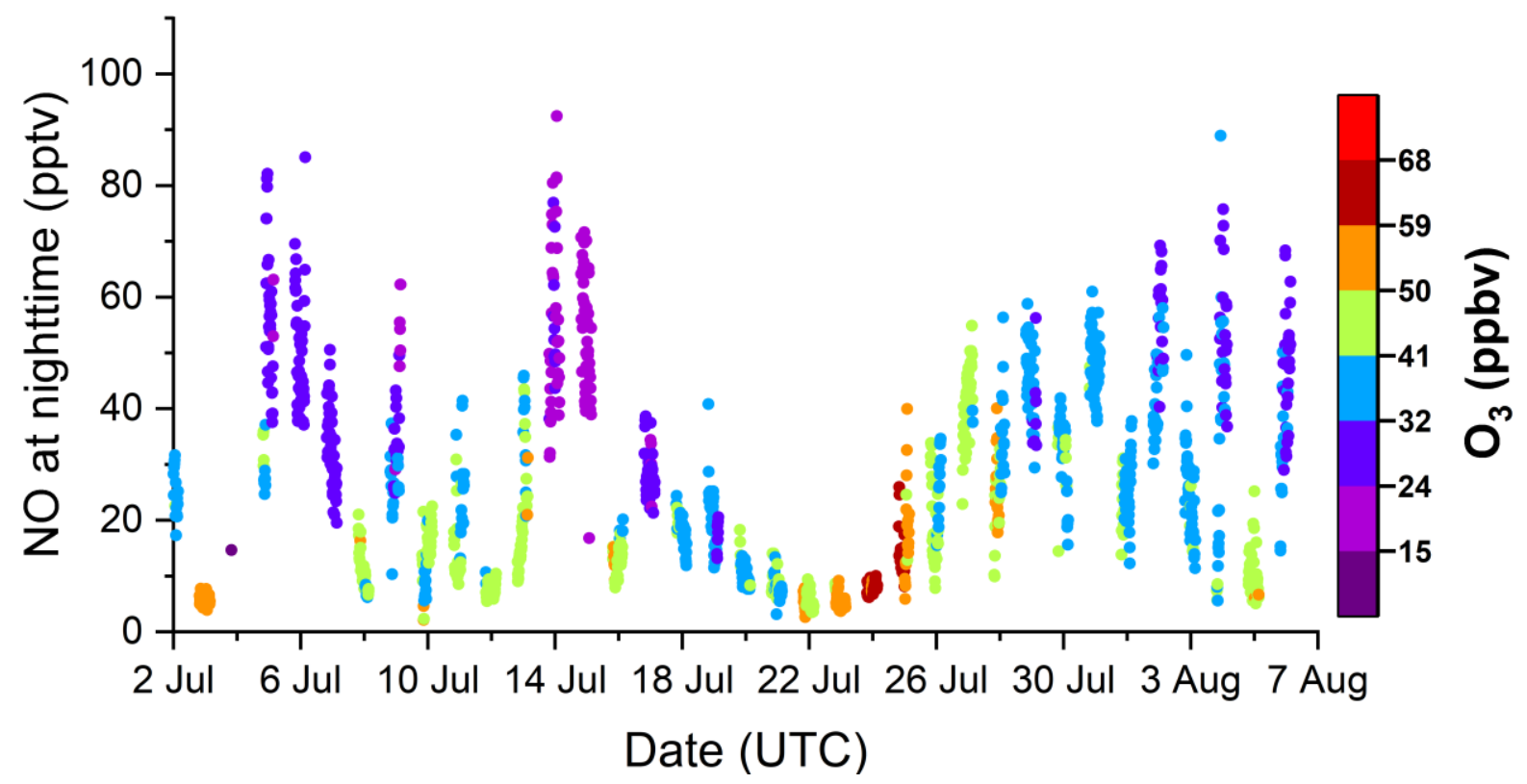

810

Figure 8: Nighttime NO mixing ratios (colour-coded by $\mathrm{O}_{3}$ mixing ratios) during TO2021. The $\mathrm{x}$-axis Ticks represent 00:00 UTC. 


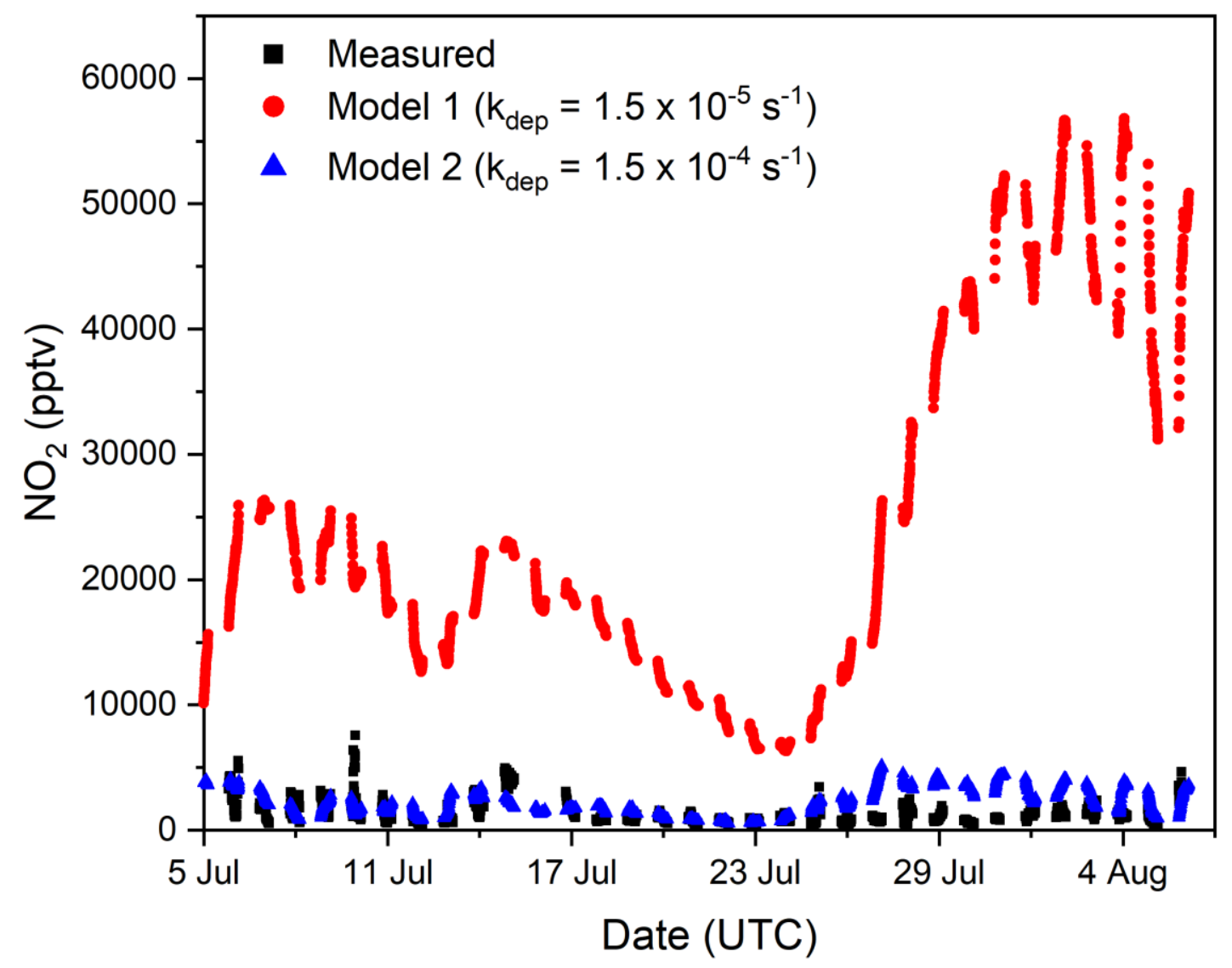

Figure 9: Time-series of measured nighttime $\mathrm{NO}_{2}$ mixing ratios during $\mathrm{TO} 2021$ (black squares) and modelled $\mathrm{NO}_{2}$ mixing ratios using deposition loss constants of $1.5 \times 10^{-5} \mathrm{~s}^{-1}$ (Model 1, red circles) and $1.5 \times 10^{-4} \mathrm{~s}^{-1}$ (Model 2, blue triangles). 
https://doi.org/10.5194/acp-2022-163

Atmospheric

Preprint. Discussion started: 7 March 2022

(c) Author(s) 2022. CC BY 4.0 License.

(c) $\underset{\mathrm{BY}}{\mathrm{B}}$

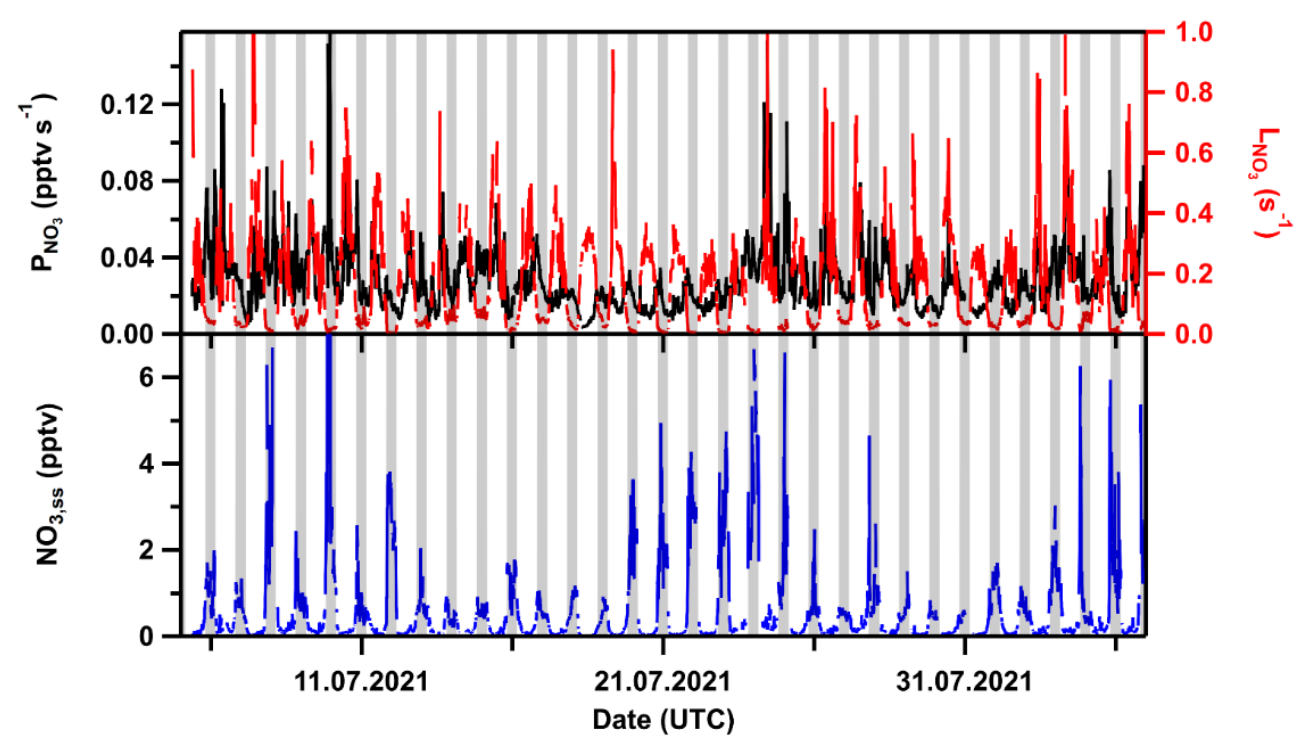

Figure 10: Upper panel: $\mathrm{NO}_{3}$ production (left) and loss rates (right) during $\mathrm{TO} 2021$. Lower panel: steady-state $\mathrm{NO}_{3}$ mixing ratios. Ticks represent 00:00 UTC. Grey shaded areas denote nighttime. 


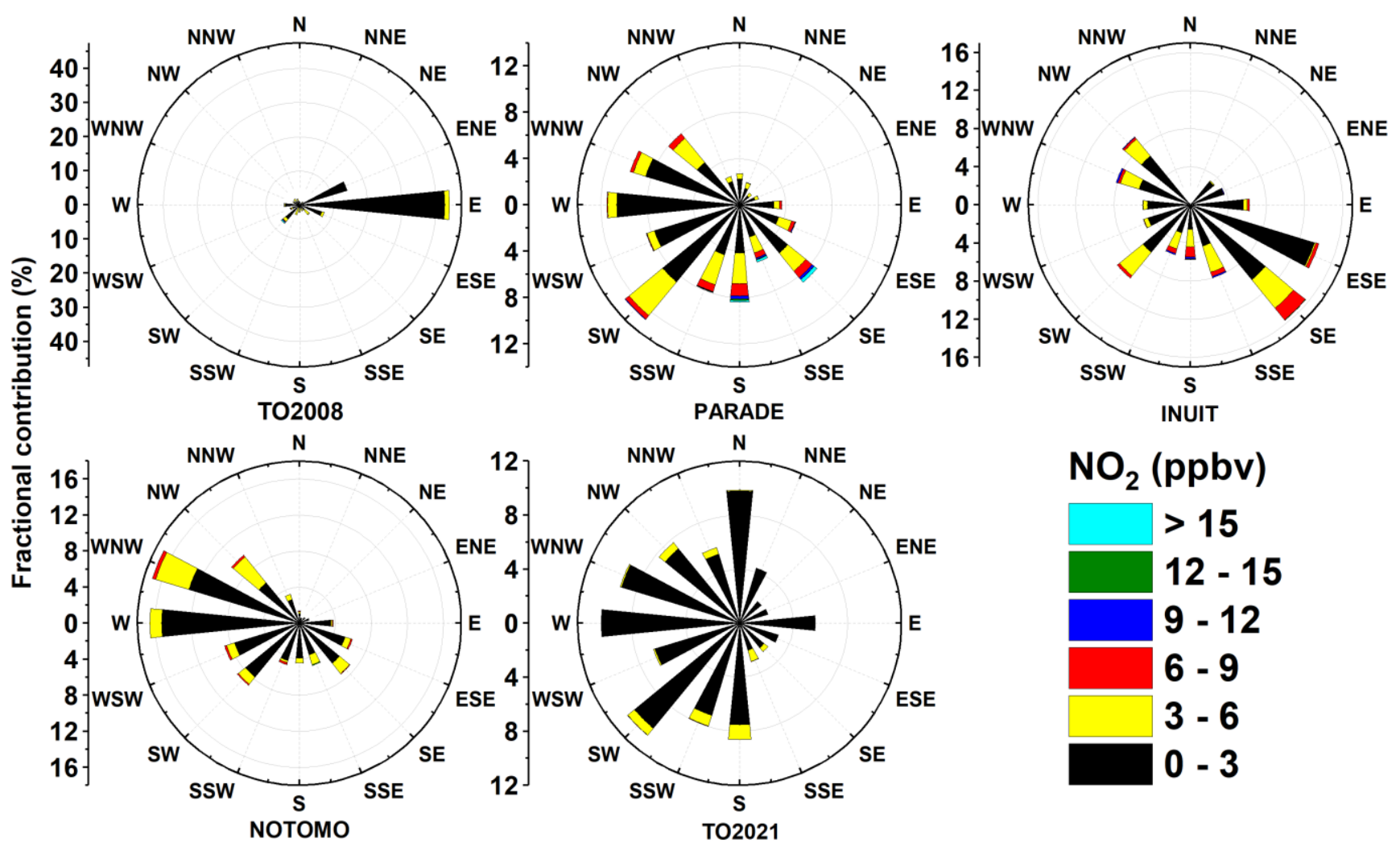

835 Figure 11: Wind roses indicating the dependence of $\mathrm{NO}_{2}$ mixing ratio on the wind direction during TO2008, PARADE, INUIT, NOTOMO and TO2021. Wind directions were provided by HLNUG for TO2008 and NOTOMO, by a weather station in PARADE and INUIT (Drewnick et al., 2012) and by the German meteorological service DWD in TO2021. 
https://doi.org/10.5194/acp-2022-163

Preprint. Discussion started: 7 March 2022

(c) Author(s) 2022. CC BY 4.0 License.
Atmospheric

Chemistry

and Physics

Discussions

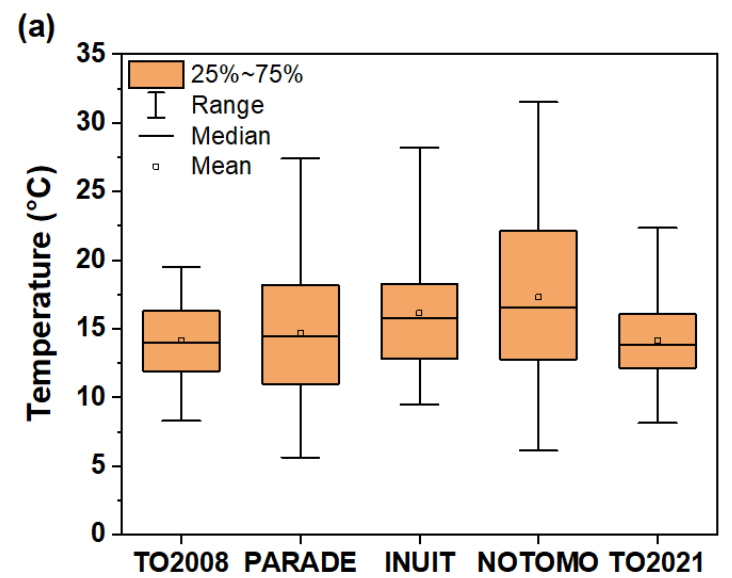

(b)

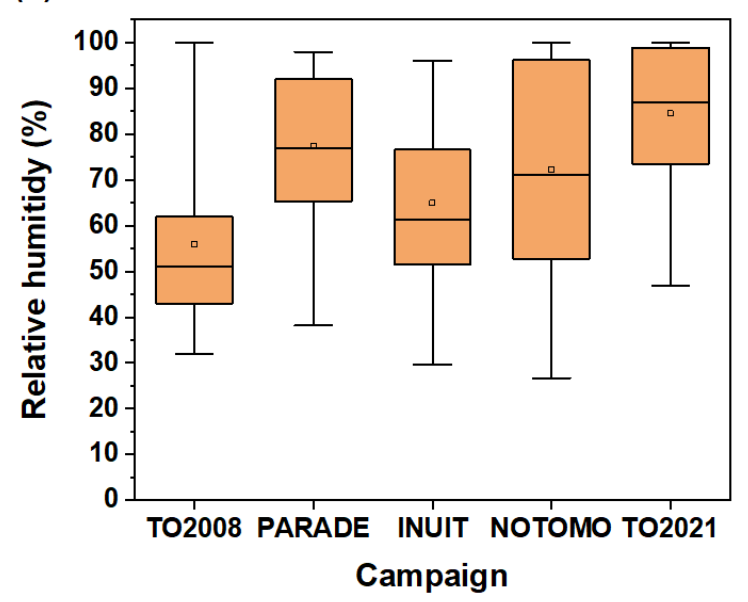

840 Figure 12: Distributions of (a) temperature and (b) relative humidity during five campaigns at the Kleiner Feldberg between 2008 and 2021. Boxes represent the range between the first and third quartiles, whiskers denote the full range of values. 

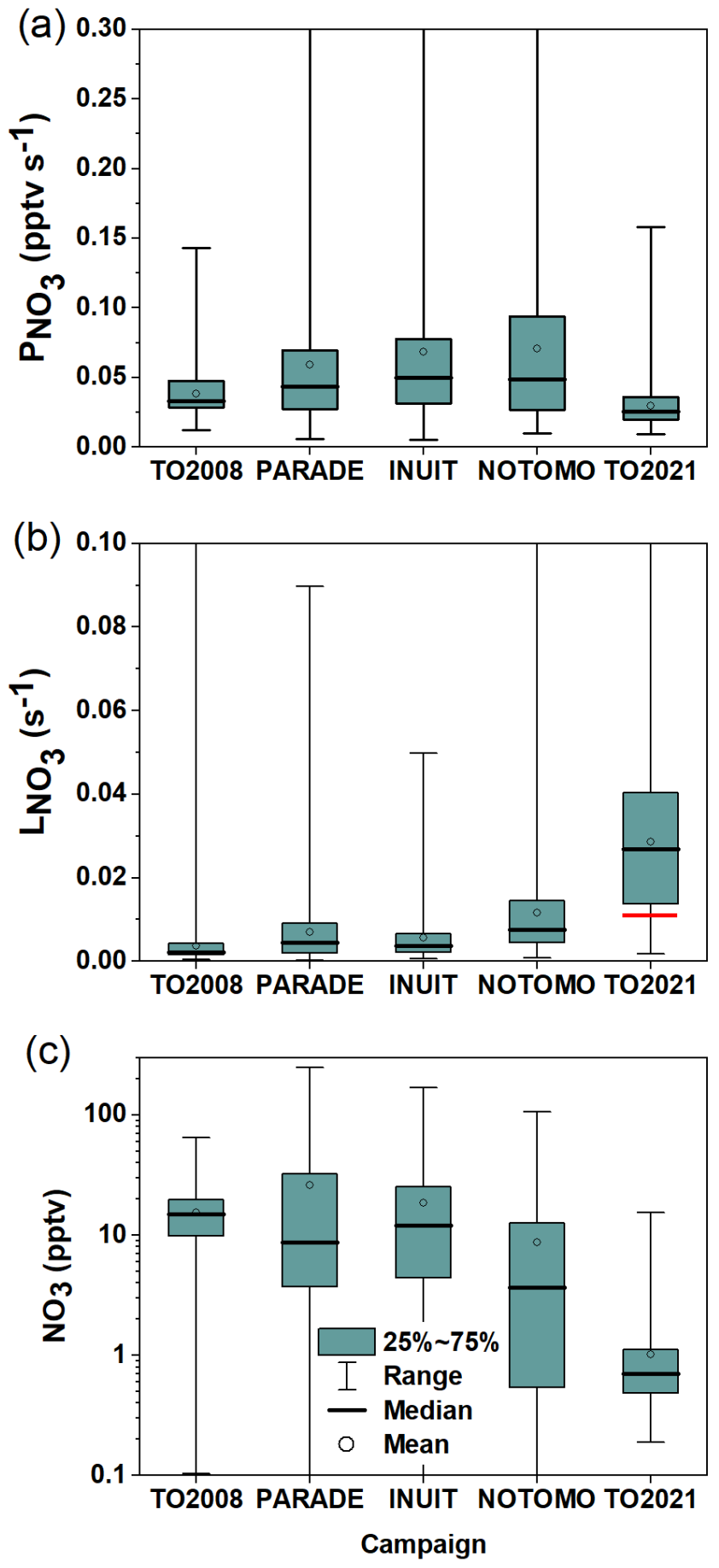

845 Figure 13: $\mathrm{NO}_{3}$ production rates (a), loss rates (b) and mixing ratios (c) measured during 5 campaigns on the summit of Kleiner Feldberg between 2008 and 2021. Boxes represent the range between the first and third quartiles, whiskers denote the full range of values. The red line represents the median of directly measured $k^{\mathrm{NO}_{3}}$ during TO2021 at nighttime. 